\title{
Review \\ Ethanol-Induced Cell Damage Can Result in the Development of Oral Tumors
}

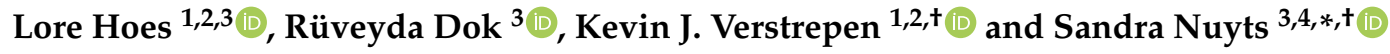 \\ 1 Laboratory for Systems Biology, VIB-KU Leuven Center for Microbiology, 3000 Leuven, Belgium; \\ lore.hoes@kuleuven.be (L.H.); kevin.verstrepen@kuleuven.be (K.J.V.) \\ 2 Laboratory of Genetics and Genomics, Centre for Microbial and Plant Genetics, KU Leuven, \\ 3000 Leuven, Belgium \\ 3 Laboratory of Experimental Radiotherapy, Department of Oncology, KU Leuven, 3000 Leuven, Belgium; \\ ruveyda.dok@kuleuven.be \\ 4 Department of Radiation Oncology, Leuven Cancer Institute, University Hospital Leuven, \\ 3000 Leuven, Belgium \\ * Correspondence: sandra.nuyts@uzleuven.be; Tel.: +32-1634-7600; Fax: +32-1634-7623 \\ + These authors contributed equally to this work.
}

check for

updates

Citation: Hoes, L.; Dok, R.; Verstrepen, K.J.; Nuyts, S.

Ethanol-Induced Cell Damage Can Result in the Development of Oral

Tumors. Cancers 2021, 13, 3846.

https://doi.org/10.3390/

cancers 13153846

Academic Editors: Pierre Saintigny, Senada Koljenović, Paolo Bossi and Jebrane Bouaoud

Received: 15 June 2021

Accepted: 27 July 2021

Published: 30 July 2021

Publisher's Note: MDPI stays neutral with regard to jurisdictional claims in published maps and institutional affiliations.

Copyright: (c) 2021 by the authors. Licensee MDPI, Basel, Switzerland. This article is an open access article distributed under the terms and conditions of the Creative Commons Attribution (CC BY) license (https:// creativecommons.org/licenses/by/ $4.0 /)$.
Simple Summary: Alcohol consumption is linked to $26.4 \%$ of all lip and oral cavity cancer cases worldwide. Despite this clear causal relationship, the exact molecular mechanisms by which ethanol damages cells are still under investigation. It is well-established that the metabolism of ethanol plays an important role. Ethanol metabolism yields reactive metabolites that can directly damage the DNA. If the damage is repaired incorrectly, mutations can be fixed in the DNA sequence. Whenever mutations affect key regulatory genes, for instance cell cycle regulating genes, uncontrolled cell growth can be the consequence. Recently, global patterns of mutations have been identified. These so-called mutational signatures represent a fingerprint of the different mutational processes over time. Interestingly, there were ethanol-related signatures discovered that did not associate with ethanol metabolism. This finding highlights there might be other molecular effects of ethanol that are yet to be discovered.

Abstract: Alcohol consumption is an underestimated risk factor for the development of precancerous lesions in the oral cavity. Although alcohol is a well-accepted recreational drug, $26.4 \%$ of all lip and oral cavity cancers worldwide are related to heavy drinking. Molecular mechanisms underlying this carcinogenic effect of ethanol are still under investigation. An important damaging effect comes from the first metabolite of ethanol, being acetaldehyde. Concentrations of acetaldehyde detected in the oral cavity are relatively high due to the metabolization of ethanol by oral microbes. Acetaldehyde can directly damage the DNA by the formation of mutagenic DNA adducts and interstrand crosslinks. Additionally, ethanol is known to affect epigenetic methylation and acetylation patterns, which are important regulators of gene expression. Ethanol-induced hypomethylation can activate the expression of oncogenes which subsequently can result in malignant transformation. The recent identification of ethanol-related mutational signatures emphasizes the role of acetaldehyde in alcoholassociated carcinogenesis. However, not all signatures associated with alcohol intake also relate to acetaldehyde. This finding highlights that there might be other effects of ethanol yet to be discovered.

Keywords: oral potentially malignant disorders; oral squamous cell carcinoma; ethanol; molecular alterations; mutational signatures

\section{Alcohol Consumption and Its Adverse Effects Know a Long History}

The first traces of alcohol fermentation already date back from 7000 before Christ [1]. Throughout the early modern period, consumption of alcohol vastly increased. In the 1500s, average alcohol consumption reached a hundred liters per person per year in 
Spain and Poland. The English population consumed on average seventeen pints (beer or ale) per week in contrast to an average of three pints today [2]. With this increasing consumption of alcoholic beverages, physicians started to notice the adverse effects of alcohol. Already in the eleventh century, a physician in Constantinople reported liver inflammation due to excessive wine drinking [2,3]. However, it was only until the late eighteenth century that alcohol addiction and abuse were acknowledged as physical and mental health problems [4]. In the early twentieth century, professor R. Pearl published his research about alcohol and longevity. He found that heavy alcohol consumption was associated with higher mortality rates $[5,6]$. Thereafter, research on how alcohol consumption is related to several medical conditions gained momentum which contributed substantially to our current knowledge on the health effects of ethanol [6].

Evidently, heavy alcohol consumption negatively impacts human health. Alcohol damages nearly every organ in the human body. In fact, more than 60 different diseases and conditions have been causally linked to alcohol consumption [6-8]. In 2016, the World Health Organization (WHO) estimated that 3 million deaths worldwide were attributable to alcohol consumption $[7,8]$. Globally, the use of alcohol was ranked as the seventh leading risk factor for both deaths and disability-adjusted life-years in 2016 [7]. Alcohol use is mostly associated with non-communicable diseases including malignant neoplasms (cancer), diabetes mellitus, alcohol use disorders, cardiovascular diseases, and alcohol liver diseases [9,10]. Specifically for cancer, Praud et al. quantified that in 2012 770,000 cancer cases were associated with alcohol consumption. This roughly corresponded to $5.5 \%$ of all cancer cases worldwide [11]. This estimate was recently updated in the population-based study published by Rumgay et al. in The Lancet Oncology. In 2020, 741,300 or 4.1\% of all new cancer cases were estimated to be attributable to alcohol consumption [12]. In 2012, the International Agency for Research on Cancer (IARC) formally classified alcoholic beverages and acetaldehyde, the first metabolite of ethanol, as type I carcinogens to humans [13].

Notably, alcohol consumption has pleiotropic effects on human health and these are strongly dose-dependent. It has been suggested that low alcohol consumption has beneficial cardiovascular effects. For instance, a J-shaped relationship between alcohol intake and ischaemic heart disease was observed in the Global Burden of Disease Study in 2016 [7]. Although interesting, the topic of this review paper is the relationship of ethanol with oral carcinogenesis.

\section{Oral Cancers Are Still Frequently Diagnosed Despite Avoidable Risk Factors}

Oral cancers are a defined subset of head and neck cancers. These include cancers of the tongue, the floor of the mouth, cheeks, palate, lips, or gums but exclude cancers of the pharynx and larynx, corresponding to the International Classification of Diseases, 10th revision codes C00-C06 [14]. These oral cancers almost exclusively consist of oral squamous cell carcinomas (OSCCs) [15]. Additionally, there is a gender discrepancy as oral cancers are particularly common in men $[15,16]$. A possible reason for this is that men are generally more exposed to risk factors as discussed in the next paragraph. In 2018, 354,864 new patients were diagnosed with lip or oral cavity cancers corresponding to $2 \%$ of the total amount of new cancer cases [17]. Many of these cases occur in low- and middle-income countries, e.g., India, Pakistan, or Tanzania, making it the fourth most common type of cancer in these countries [14]. Despite advances in treatment, the overall five-year survival rate for oral cancers is only $50-55 \%$ [18]. Oral carcinogenesis is a complex multistep process that takes place over many years $[16,19]$. Genetic alterations of squamous cells can lead to uncontrolled cell growth, a hallmark of cancer. There exist multiple oral potentially malignant disorders (OPMDs) that can precede oral cancer [19]. Frequently diagnosed lesions include oral leukoplakia, which are visible as white oral patches [18,20]. Other, less common, OPMDs include erythroplakia, oral submucous fibrosis, and oral lichen planus [21]. The prevalence of these lesions increases with age and early detection is crucial to avoid malignant transformation $[18,22,23]$. 
Established risk factors for developing oral malignancies include tobacco smoking or chewing, heavy alcohol drinking, and human papillomavirus (HPV) infection [18]. Firstly, tobacco is an undeniable risk factor for several cancer types, including oral cancers. Epidemiological studies associate both smoked and smokeless tobacco with the formation of tumors in the oral cavity [24-28]. Smokeless tobacco, for instance, enhances the incidence of oral cancers almost fourfold, based on results from 36 independent studies [28]. It should be noted however that this association is dependent on geographical location, as not all studies conducted in Europa and North-America found a significant association between smokeless tobacco and increased risk of oral tumors $[27,28]$. Secondly, tobacco use is often accompanied by alcohol consumption. Tobacco and alcohol have a major synergistic effect on the development of oral cancerous lesions [29-32]. The increase of the odds ratio depends on the dose of both alcohol and tobacco [31]. Together, tobacco and alcohol use account for approximately $75 \%$ of oral cancers [33]. Despite the synergistic effect of tobacco combined with alcohol, also alcohol on its own is a considerable risk factor for oral cancers [34]. The role of alcohol in oral carcinogenesis will be elaborated in the next section. Men tend to drink and smoke more compared to women, which might be the reason why oral cancers are so common in men $[35,36]$. Lastly, infection with HPV, especially high-risk HPV16 or HPV18, is a well-recognized risk factor for oropharyngeal cancers $[37,38]$. The prevalence of HPV infections in oral cancers is also significant in some geographic locations, e.g., around 36\% in India and Japan [39]. In contrast, only $2.2 \%$ of oral tumors were positive for HPV in a Dutch cohort [40]. $\mathrm{HPV}^{+}$tumors show a distinctly different molecular and mutational landscape compared to HPV ${ }^{-}$tumors [38]. Overall, HPV positivity is associated with a better prognosis $[39,41]$.

\section{Alcohol Is an Independent Risk Factor for Oral Carcinogenesis}

Although alcoholic beverages consist of multiple components, this review will solely focus on ethanol. Quantification of the amount of ethanol consumed is critical to assess the effects of this compound on the incidence of specific tumors. Different studies use different measures and thresholds to define low, moderate, and heavy drinking. For instance, the definition of a 'standard drink', which originated from governmental guidelines, is highly variable between countries. In Belgium and France, one standard drink contains $10 \mathrm{~g}$ of pure ethanol. In contrast, a standard drink holds $14 \mathrm{~g}$ and even $20 \mathrm{~g}$ of ethanol in the US and Austria respectively [42,43]. Therefore, the comparison of different studies is not always straightforward. In this review, the unit used to compare studies is always grams of pure ethanol.

\subsection{Epidemiological Data Indicate a Strong Correlation between Alcohol and Oral Malignancies}

Long-term ethanol exposure results in the formation of tumors all over the human body. Clear causal relationships have been identified for (at least) seven different types of cancer. The strongest associations were observed for cancers originating in the oral cavity, pharynx, larynx, and esophagus [44-49]. Specifically for oral cancers, alcohol consumption is a substantial risk factor with a clear dose-response relationship [50-55]. Studies from various geographical areas show elevated odds ratios for oral cancers in combination with ethanol intake [56-62]. For instance, consumption of more than $40 \mathrm{~g}$ of pure ethanol daily, was shown to result in a threefold increased risk for developing oral tumors in Indian men [63]. A Spanish case-control study also confirmed elevated odds ratios of oral cancer associated with ethanol. Heavy drinking, defined as $>50 \mathrm{~g}$ of ethanol a day, resulted in an odds ratio of 5.04 [64]. It should be noted however that this study also included oropharyngeal cancers when defining oral cancers. Recently, Griswold et al. performed an extensive meta-analysis, combining data from almost 600 studies, concerning the role of alcohol in disease. This analysis shows that the relative risk for developing mouth and lip cancers in men increases linearly with the amount of alcohol consumed [7]. This result also highlights that there is no 'safe' level of drinking when the incidence of oral tumors is evaluated. Noteworthy, lip cancer is often grouped together with oral cavity cancers. 
However, the main risk factors for developing (outer) lip cancer are tobacco and UV exposure $[65,66]$. Also, data from the International Head and Neck Cancer Epidemiology consortium confirmed that alcohol is an independent risk factor for cancers of the oral cavity, oropharynx, hypopharynx, and larynx [55]. Odds ratios for cancers of the oral cavity increased linearly with the number of drinks a day. The curve however flattened when more than 5 drinks (i.e., $60 \mathrm{~g}$ of pure ethanol) were consumed daily. Interestingly, the bivariate spline models suggested that the duration of drinking (measured in years) does not affect the odds ratio for oral cavity cancers [55]. In other words, the risk of developing oral cavity tumors does not increase when patients drink the same amount of alcohol for a longer time. Noticeably, some studies did not find significant associations between ethanol and the incidence of oral tumors [49,67-69]. Sometimes, only increased odds for oral cancers can be found when patients do not only drink alcohol but also smoke tobacco. Indeed, ethanol is believed to increase membrane permeability of the oral mucous layer which subsequently leads to increased exposure to tobacco carcinogens [70]. Although multiple studies (cited above) showed a linearly increasing relationship between alcohol and oral tumor incidence, the role of low alcohol consumption in oral carcinogenesis remains controversial. For instance, results of a cohort study conducted in the Netherlands showed that drinking less than $15 \mathrm{~g}$ of ethanol per day did not significantly increase the risk for developing oral cavity cancer [60].

In addition to associations of oral carcinomas with ethanol intake, OPMDs have also been investigated. A large prospective study evaluated the link between ethanol exposure and occurrence of OPMDs in men [71]. Lesions taken into account in this study include leukoplakia, erythroplakia, erythroleukoplakia, oral lichen planus, and oral epithelial dysplasia. The multivariate relative risk for developing oral lesions was 2.5 for men who drank more than $15 \mathrm{~g}$ of pure ethanol daily (which roughly corresponds to $380 \mathrm{~mL}$ of a light beer containing 5\% ethanol) [71]. A case-control study from Puerto Rico did however not find a significant positive association between the risk for developing OPMDs and ethanol exposure [72]. Similarly, cross-sectional studies conducted in India and Cambodia did not find a significant influence of alcohol drinking on the incidence of OPMDs [73,74]. Recently, however, several meta-analyses evaluated the malignant transformation risk for oral lichen planus, which is a chronic inflammation of the oral mucous membranes. While the overall malignant transformation rate is low $(\sim 1 \%)$, alcohol consumption significantly increases the risk for malignancies emerging from oral lichen planus [75-77].

The studies above are mostly using classical or observational epidemiology to investigate the potential carcinogenic role of ethanol. Since the last decade, however, genetic epidemiology is gaining popularity. In this field, Mendelian randomization (MR) is used to investigate causal exposure-disease interactions. MR employs the random assignment of genes during gamete formation to reduce confounding, which was extensively reviewed by Smith et al. [78]. In short, the first step is to identify genetic variants which are directly associated with the exposure. The next step for MR is to divide the study population into two groups based on these specific polymorphisms linked to the exposure. Lastly, the incidence/risk of the disease of interest is investigated in both groups to assess if the exposure is indeed causally linked to the disease [78]. Considering ethanol, there are known polymorphisms in ethanol-metabolizing genes which alter exposure to ethanol [78,79]. For instance, carrying the $A D H 1 B$ rs1229984 polymorphism was associated with less ethanol intake [80]. Recently, many more variants related to alcohol use have been identified [81]. Using MR, Gormley et al. confirmed that both alcohol and tobacco are independent risk factors for oral and oropharyngeal cancers with inverse variance weighted odds ratios of 2.1 and 2.6 respectively [82].

\subsection{In Vivo Data Support a Causal Effect of Alcohol on Oral Tumor Incidence}

It is important to acknowledge that association studies do not necessarily imply a causal relationship between ethanol and oral cancers. It is well-known that confounders or reverse causality can result in spurious associations [78]. Therefore, multiple in vivo 
studies have been conducted as well to assess the carcinogenic effect of ethanol. Often, the consequence of ethanol exposure is evaluated in chemically-induced cancer models. This way, it was observed that $8 \%$ ethanol administration in addition to 4-nitroquinoline-1oxide, a toxic quinoline which induces oral tumors [83], promotes malignant transformation in C57BL/6J mice [84]. Also in male Fischer-344 rats, $7 \%$ ethanol administration on top of $\mathrm{N}^{\prime}$-nitrosonornicotine or 4-(methylnitrosamino)-1-(3-pyridyl)-1-butanone increased the incidence of oral tumors two-fold [85]. Importantly, Soffritti et al. also performed an in vivo study without an additional carcinogenic chemical. In their experiment, Sprague-Dawley rats were exposed to $10 \%$ ethanol ad libitum for about 3 years (until spontaneous death). Ethanol administrated rats developed tumors at various sites, including malignant tongue, lip, and oral cavity tumors [86].

Additionally, rabbits solely exposed to ethanol for 12 months developed leukoplakialike epithelial dysplasia, which is a common OPMD that can be a progenitor stage of squamous cell carcinomas $[87,88]$. Also more dysplasia was detected in tongue and pharynx tissues of Wistar rats exposed to 30\% ethanol ad libitum for 260 days [89].

Based on these in vivo and epidemiology data, the IARC concluded there is indeed a causal relationship between ethanol exposure and oral carcinogenesis. Interestingly, however, the exact molecular mechanisms whereby ethanol can induce OPMDs or tumor formation are still not fully understood. In the following sections of this review, we will address precisely this question.

\section{Various Molecular Alterations Have Been Attributed to Ethanol}

\subsection{Acetaldehyde Can Accumulate in the Oral Cavity}

Ethanol is known to damage eukaryotic cells in different ways. Mostly, its carcinogenic effects are assigned to the intermediary metabolites, acetaldehyde and reactive oxygen species (ROS), formed during oxidative ethanol metabolism. Multiple enzymes are involved in the conversion of ethanol. A concise overview of ethanol metabolism and genes involved is given in Figure 1. Alcohol dehydrogenases (ADHs) convert a considerable part of the ethanol into acetaldehyde. Additionally, cytochrome P450 enzymes (CYP), mostly CYP2E1, can oxidize ethanol into acetaldehyde as part of the microsomal ethanol oxidizing system (MEOS). Thereafter, aldehyde dehydrogenases (ALDHs) further metabolize acetaldehyde which yields acetate. ROS can either be generated directly, during the conversion of ethanol into acetaldehyde by CYP2E1, or indirectly, when NADH is re-oxidized to $\mathrm{NAD}^{+}$in the mitochondria $[90,91]$. Although the liver is the primary organ which metabolizes ethanol, expression of $A D H, C Y P$ and $A L D H$ genes have also been detected in the oral mucosa [92-94].

In the oral cavity, there is another important factor that contributes to the accumulation of acetaldehyde: the oral microbiome. Several bacterial species that belong to Streptococcus and Neisseria genera, commonly detected in the oral microbiome, have been shown to produce acetaldehyde from ethanol $[95,96]$. For instance, Neisseria mucosa, Neisseria flavescens and Streptococcus mitis were shown to produce $272.8 \pm 65.5,168.4 \pm 8.6$ and $90.2 \pm 31.3 \mu \mathrm{M}$ acetaldehyde respectively, in the presence of $11 \mathrm{mM}$ ethanol and $100 \mathrm{mM}$ glucose [97]. Homann et al. (1997) established that acetaldehyde levels in the saliva of human volunteers can reach $\sim 140 \mu \mathrm{M}$ after a moderate dose of ethanol $(0.5 \mathrm{~g}$ of ethanol $/ \mathrm{kg})$ which is 10-100 fold higher compared to blood acetaldehyde levels $(\sim 1-5 \mu \mathrm{M})[46,98]$. Alcohol consumption in combination with smoking can even increase the salivary acetaldehyde up to $400 \mu \mathrm{M}$ [99]. This concentration easily reaches the carcinogenic threshold, defined as acetaldehyde levels above 50-100 $\mu \mathrm{M}[100,101]$. Interestingly, the composition of the oral microbiome can also be altered towards more acetaldehyde producing bacteria by heavy alcohol consumption and tobacco smoking $[95,102,103]$.

A last source of acetaldehyde in the oral cavity is the alcoholic beverage itself. Lachenmeier and Sohnius chemically analyzed more than 1500 beverages and quantified acetaldehyde concentrations using gas chromatography. They concluded that beer, wine, and spirits contain on average $0.204 \mathrm{mM}, 0.765 \mathrm{mM}$, and $1.48 \mathrm{mM}$ acetaldehyde respectively [100]. 


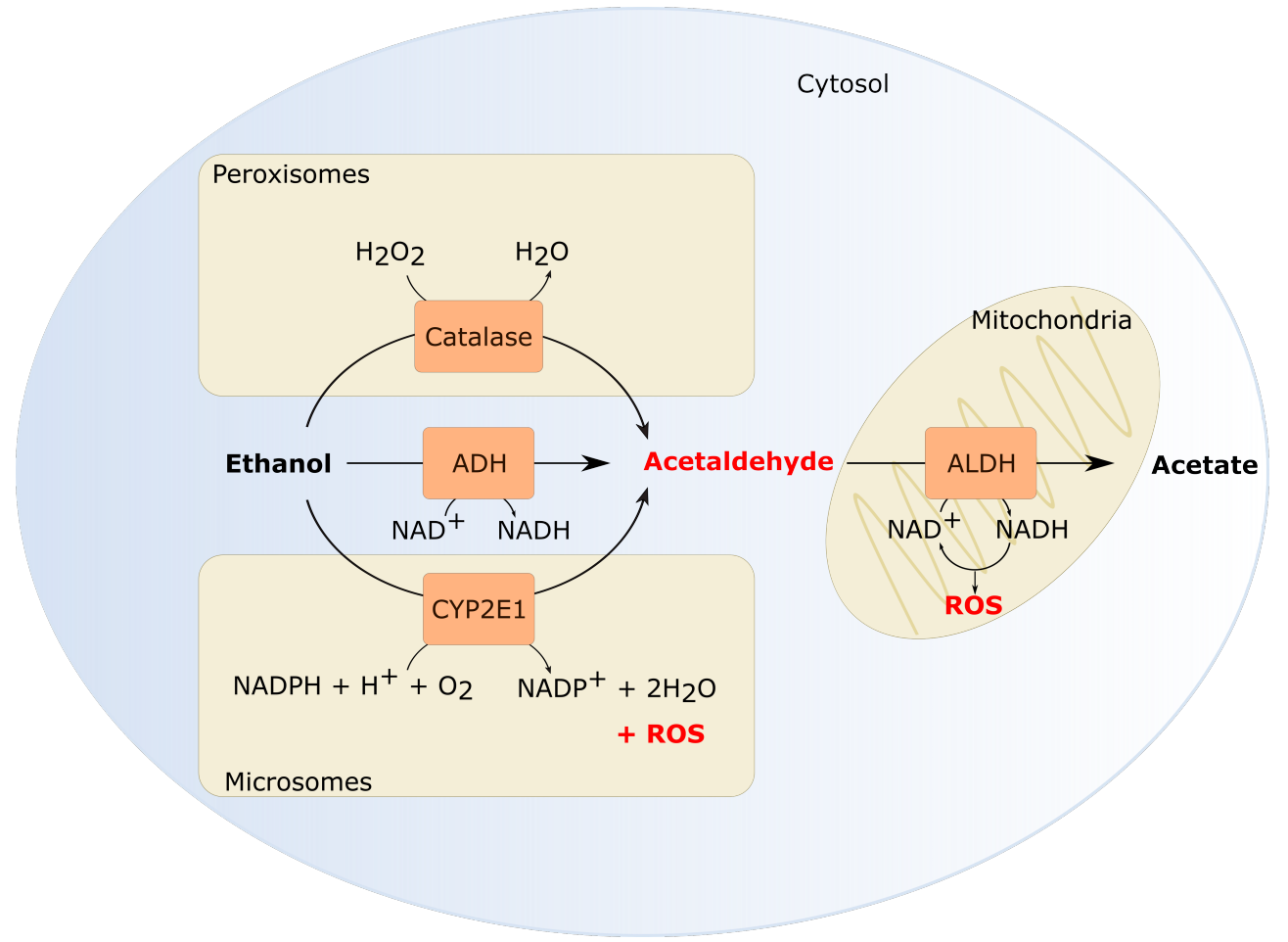

Figure 1. Oxidative ethanol metabolism generates reactive metabolites. Several enzymes catalyze ethanol oxidation into acetaldehyde. The cytosolic alcohol dehydrogenase (ADH) contributes the most to the formation of acetaldehyde [104]. Additionally, CYP2E1, active in the MEOS, can oxidize ethanol. Also CYP1A2 and CYP3A4 contribute to ethanol oxidation in the MEOS [105-107]. In normal physiological conditions, MEOS is only responsible for $25-30 \%$ of the ethanol oxidation. However, CYP2E1 activity increases significantly by heavy alcohol consumption [108-110]. CYP2E1 activity in the MEOS does not only generate acetaldehyde but also ROS which is another important metabolite of ethanol. Lastly, catalase can oxidize ethanol through the formation of hydroxyl radicals [111]. Catalase is especially important in the brain or in a fasted state [104,112,113]. In the next step, acetaldehyde is oxidized to acetate by aldehyde dehydrogenase (ALDH). Acetate is excreted from the cells into the systemic circulation where it can eventually be metabolized to carbon dioxide [104]. Both $\mathrm{ADH}$ and $\mathrm{ALDH}$ enzyme activity results in a decreased $\mathrm{NAD}^{+} / \mathrm{NADH}$ ratio. $\mathrm{NADH}$ reoxidation in the mitochondria can also generate ROS.

\subsection{Metabolites of Ethanol Can Directly Affect the DNA by Formation of Adducts and Crosslinks} 4.2.1. Acetaldehyde-Derived DNA Adducts and Crosslinks

Acetaldehyde can directly interact with the DNA base pairs resulting in DNA adducts (Figure 2). The first and most abundant adduct is $\mathrm{N}^{2}$-ethyl-2'-deoxyguanosine $\left(\mathrm{N}^{2}\right.$ EtdG) $[114,115]$. $\mathrm{N}^{2}$-EtdG originates from $\mathrm{N}^{2}$-ethylidene-2'-deoxyguanosine $\left(\mathrm{N}^{2}\right.$-EtidG) which is produced via direct interaction of a single acetaldehyde molecule with deoxyguanosine (dG). However, this Schiff base is unstable in vivo (half-life of $24 \mathrm{~h}$ at $37^{\circ} \mathrm{C}$ ), but reduction by e.g., vitamin $C$ or glutathione yields the stable $\mathrm{N}^{2}$-EtdG adduct $[114,115]$. In vitro experiments showed that $\mathrm{N}^{2}$-EtdG can block the replicative DNA polymerase $\alpha$ [116] in contrast to DNA polymerase $\delta$ which was not significantly blocked by this small adduct [117]. Upon blockage of a replicative polymerase, this lesion can be efficiently bypassed by translesion DNA polymerase $\eta[116,117]$. In vivo data are in agreement with these earlier findings. Translesion polymerases are probably the most important way to remove this lesion, as BER or direct repair have not been shown to repair $\mathrm{N}^{2}$. EtdG [101]. Resolution of the $\mathrm{N}^{2}$-EtdG block by translesion DNA polymerases mostly results in frameshift mutations that are weakly mutagenic [101,118]. Extrapolating the consequences seen for $\mathrm{N}^{2}$-EtdG to $\mathrm{N}^{2}$-EtidG should however be done with caution as these adducts interact differently with deoxycytidine (dC). $\mathrm{N}^{2}$-EtdG forms three hydrogen bonds 
with $\mathrm{dC}$ while $\mathrm{N}^{2}$-EtidG can only form two, which renders a G:C base pair that is only as stable as an A:T base pair [101].

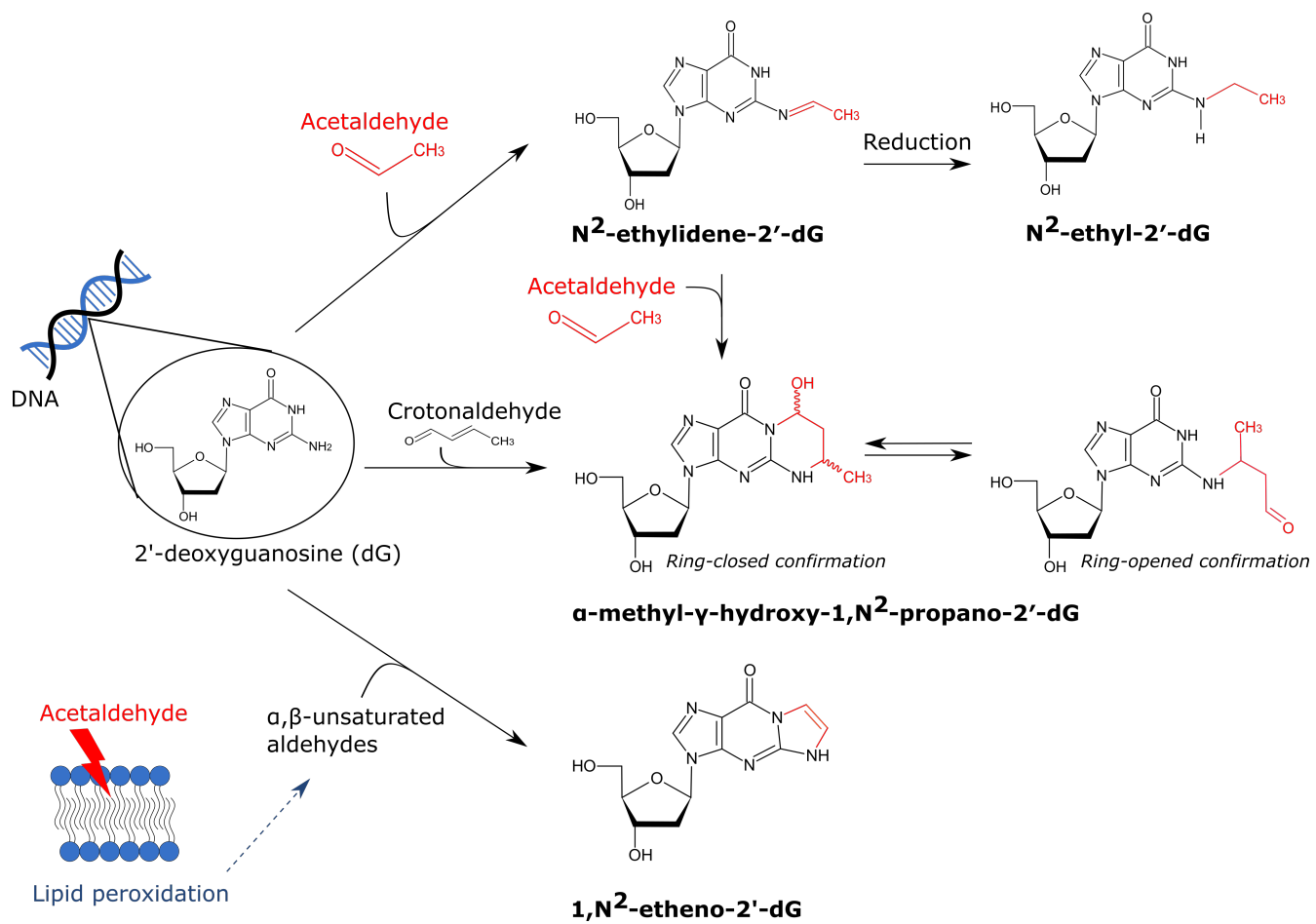

Figure 2. Overview of acetaldehyde-derived DNA adducts. Acetaldehyde can interact with dG which results in several adducts. The first and most abundant acetaldehyde-derived dG adduct is $\mathrm{N}^{2}$-ethylidene-2'-dG. It can be converted into the stable $\mathrm{N}^{2}$-ethyl-2'-dG by reduction by e.g., glutathione. A second adduct is $\alpha$-methyl- $\gamma$-hydroxy-1, $\mathrm{N}^{2}$-propano- $2^{\prime}-\mathrm{dG}$ which is formed by the interaction of either two molecules of acetaldehyde or crotonaldehyde with dG. It was suggested that in physiologically relevant conditions, two molecules of acetaldehyde are first converted into crotonaldehyde which can subsequently interact with $\mathrm{dG}$ [119]. This adduct can exist in a ring-closed or ring-opened confirmation. In the latter case, it can induce interstrand crosslinking (not visualized). Lastly, acetaldehyde can induce lipid peroxidation thereby forming $\alpha, \beta$-unsaturated aldehydes. These aldehydes can also interact with $\mathrm{dG}$, resulting in $1, \mathrm{~N}^{2}$-etheno- $2^{\prime}$-dG.

A second important adduct is $\alpha$-methyl- $\gamma$-hydroxy- $1, \mathrm{~N}^{2}$-propano-2'-deoxyguanosine, also referred to as crotonaldehyde-derived N2-propanodeoxyguanosine (Cr-PdG) [46,119]. For the formation of $\mathrm{Cr}-\mathrm{PdGs}$, two molecules of acetaldehyde are necessary as was unequivocally shown by Garcia et al. [120]. In physiologically relevant conditions (100 $\mu \mathrm{M}$ acetaldehyde), polyamines probably convert two acetaldehydes into crotonaldehyde which in turn can interact with dG forming Cr-PdG [119]. Although less abundant, Cr-PdG adducts are more mutagenic compared to $\mathrm{N}^{2}$-EtdG. Cr-PdG adducts can exist in a ringopened or a ring-closed confirmation. In a ring-closed state, $\mathrm{Cr}$-PdG inhibits base pairing with $\mathrm{dC}$ which could result in replication blocking [121]. In a ring-open state however, a reactive aldehyde group is exposed which can interact with proteins or dG resulting in DNA-protein and DNA-DNA interstrand and possibly also intrastrand crosslinks [121]. Multiple repair pathways have been shown to be involved in Cr-PdG repair, including nucleotide excision repair and translesion polymerase synthesis [122,123]. Interstrand crosslinks (ICLs) are primarily repaired by the Fanconi anemia (FA) pathway. Acetaldehyde hypersensitivity was detected in FA-deficient DT40 chicken B-cells, mice and DLD1 human cells which highlights the importance of the FA repair pathway for acetaldehydeinduced damage [124-126]. The FA repair is initiated when the FANCM-FAAP24-MHF1/2 complex recognizes the stalled replication fork due to an ICL. Subsequently, unhooking of the ICLs takes place by specific nucleases and this converts the stalled replication fork into 
a double-strand break (DSB), on one end, and unhooked ICL, on the other end. Translesion DNA synthesis can bypass the unhooked crosslinked nucleotide to restore the nascent DNA strand. To repair the DSB, mostly homologous recombination is used [127]. The FA repair pathway always introduces a DSB which can induce large genomic instability when it gets exposed. However recently, Hodskinson et al. unexpectedly discovered a new and faster pathway to repair ICLs [128]. This new route also requires replication fork convergence but does not cut the DNA which yields a safer fix for ICLs [128]. This finding might indicate that acetaldehyde induces less DSBs in vivo than was initially assumed. Nevertheless, acetaldehyde induced DNA crosslinks can still be mutagenic as the repair still requires error-prone polymerases such as REV1 and pol $\zeta$ [128].

A third DNA adduct that was detected after acetaldehyde exposure is $1, \mathrm{~N}^{2}$-etheno$2^{\prime}$-deoxyguanosine (NedG). This adduct is suggested to result from lipid peroxidation and not a direct interaction between acetaldehyde and the DNA. More specifically, acetaldehyde can induce lipid peroxidation in which epoxidized $\alpha, \beta$-unsaturated aldehydes are formed that can subsequently interact with dG which results in $\mathrm{N} \epsilon \mathrm{dG}[120,121,129]$. Garcia et al. showed that exposure of IMR-90 primary human lung fibroblasts to $155 \mu \mathrm{M}$ for $3 \mathrm{~h}$ significantly increased $\mathrm{N} \epsilon \mathrm{dG}$ adduct formation [120]. This concentration can easily be reached in the saliva, as discussed before. The mutagenic consequences of $\mathrm{N} \epsilon \mathrm{dG}$ are not fully understood yet. In vitro, this adduct blocks the replicative DNA polymerase $\delta$ and bypass of this lesion by error-prone polymerases is needed which has varying mutagenic consequences [130]. However, in vivo data hypothesized that $\mathrm{N} \epsilon \mathrm{dG}$ leads to replication fork collapse and generation of DSBs, but this was not yet confirmed by other studies [121]. How this adduct is repaired is still uncertain. It was previously thought that BER is the main route for repair, but recently Thelen et al. showed that alkyladenine DNA glycosylase cannot use N $\epsilon \mathrm{dG}$ as a substrate [131].

In adult Rhesus monkeys exposed to ethanol, $\mathrm{N}^{2}$-EtdG levels were 2.8 fold increased, as analyzed by LC-ESI-MS/MS [132]. The animals consumed ethanol (5\% in water) ad libitum for 12 months after which mucosal tissues were isolated and analyzed [132]. The researchers estimated that the monkeys consumed on average $2.3 \pm 0.8 \mathrm{~g} / \mathrm{kg}$ of ethanol per day, which is equivalent to nine drinks containing $15 \mathrm{~g}$ ethanol each. In ALDH2-knockout mice, known to accumulate acetaldehyde, drinking of $5 \%$ ethanol for 8 weeks significantly increased esophageal $\mathrm{N}^{2}$-EtidG levels (9.73 \pm 2.33 adducts $/ 10^{7}$ bases) [133]. In addition to animal studies, acetaldehyde-derived DNA adducts have also been quantified in human individuals. For instance, increased levels of $\mathrm{N}^{2}$-EtdG were reported in lymphocytes of alcoholic patients (consumed $>50$ drinks per week) [114]. Interestingly, Balbo et al. examined the kinetics of $\mathrm{N}^{2}$-EtdG formation in oral cells of human volunteers. They observed that $\mathrm{N}^{2}$-EtdG levels increased drastically (up to 100-fold) within $4 \mathrm{~h}$ after administration of low doses of ethanol [134]. Despite a lower abundance, also Cr-PdG adducts have been observed in the DNA of human subjects. In Japanese alcoholic patients, the level of Cr-PdG adducts in blood DNA was significantly increased in patients that carried the $A L D H 2^{*} 2$ or $A L D H 2$ rs671 allele [135]. This variant of $A L D H 2$ renders an inactive enzyme and therefore individuals carrying this allele build up more acetaldehyde.

\subsubsection{ROS-Derived DNA Adducts}

ROS are always present during normal cellular metabolism, but drinking ethanol can enhance cellular ROS levels. Ethanol metabolism by CYP2E1 is predominantly causing ROS levels to rise. CYP2E1 is highly expressed in the liver making this organ highly susceptible to ethanol-induced oxidative damage [136]. But also in oral carcinogenesis, oxidative stress is an important contributor [137]. In addition to the direct formation of ROS during ethanol metabolism, abuse of alcohol can also deplete key radical scavengers such as glutathione, vitamin C, and vitamin E $[138,139]$. Mostly, vitamin depletion is linked with malnutrition in alcohol-dependent patients. Notably, also these indirect effects of alcohol abuse on oxidative stress have been mostly studied in the liver. 
ROS can result in direct oxidation of DNA base pairs and possibly even in DNA-DNA crosslinks (reviewed by [140]). An abundant lesion is 8-hydroxy-2'-deoxyguanosine (8$\mathrm{OHdG}$ ) which results from the interaction of $\mathrm{OH}^{\bullet}$ with $\mathrm{dG}$ (Figure 3A) [141]. Keto-enol tautomerism of 8-OHdG favors the oxidized product 8-oxo-7,8-dihydro-2'-deoxyguanosine (8-oxodG). In literature, both 8-OHdG and 8-oxodG refer to the same compound and this is widely used as a biomarker for oxidative stress and carcinogenesis [141]. This lesion is also mutagenic because 8-oxodG mispairs with A which results in frequent GC $\rightarrow$ TA transversions [142]. Oxidized base pairs are often efficiently removed by base excision repair (BER) [140]. Interestingly, however, ethanol can indirectly inhibit 8-oxo-guanineDNA- glycosylase 1, the primary DNA glycosylase that removes 8-oxodG, due to induction of nitric oxide [143,144].

Ethanol-induced ROS can interact with lipid molecules present in the cell membrane which results in lipid peroxidation [145]. Lipid peroxidation generates malondialdehyde (MDA) and 4-hydroxy-2-nonenal (4-HNE) [145]. MDA originates from nonenzymatic lipid peroxidation of unsaturated fatty acids and the 4-HNE from the oxidation of long-chain polyunsaturated fatty acids [146]. These products can interact with the DNA thereby forming exocyclic etheno-adducts such as $1, \mathrm{~N}^{6}$-etheno- $2^{\prime}$-deoxyadenine (NedA) and 3, $\mathrm{N}^{4}$ etheno- $2^{\prime}$-deoxycytidine (NedC) (Figure 3B) [147]. These etheno-adducts are generally repaired by BER. It is well known that $\mathrm{N} \epsilon \mathrm{dA}$ is a substrate of the alkyladenine DNA glycosylase [148]. N $\epsilon \mathrm{dC}$ on the other hand is repaired by human glycosylases SMUG1 and TDG [149,150]. If not repaired, these adducts are strongly mutagenic as they can induce multiple types of base-pair substitutions [151]. The biological relevance of 4-HNE DNA adducts is also emphasized by the finding that this was found to mutate codon 249 of human TP53 (which encodes p53) thereby giving the cells a growth advantage [152]. Notably, MDA and 4-HNE are also known to react with certain amino acids which results in protein adducts $[153,154]$. These protein adducts can be immunogenic thereby triggering tissue inflammation [146]. Tissue inflammation is especially linked to alcohol-induced liver damage, but can also play a role in oral carcinogenesis [146,155].

Gingival tissue of male Wistar rats exposed to ethanol for instance showed a significant increase of 8-OHdG and decrease of glutathione levels [139]. In Sprague-Dawley rats that chronically consumed ethanol, elevated levels of 8-oxodG were also detected in the liver and even in the esophagus, when rats received a vitamin-depleted diet [156]. Additionally, increased levels of MDA were observed in parotid and submandibular salivary glands of female Wistar rats when exposed to ethanol [157]. This study attempted to mimic binge drinking by feeding the rats an ethanol dose of $3 \mathrm{~g} / \mathrm{kg} /$ day and this for 3 days a week [157]. Also, 4-HNE levels were found to be significantly increased in tongue tissues of female mice exposed to $20 \%$ of ethanol in their drinking water for 15 weeks [158]. In human patients diagnosed with OSCC or OPMDs, including leukoplakia, oral lichen planus, and submucous fibrosis, levels of 8-OHdG and MDA were significantly increased in comparison to healthy individuals [159]. Also in a small subset of British and Japanese patients reporting alcohol misuse, protein adducts with acetaldehyde, MDA and 4-HNE were found in oral biopsies [160]. The staining of MDA-protein adducts was also significantly correlated with acetaldehyde and CYP2E1 expression [160]. In liver samples from patients with a history of alcohol abuse, the $\mathrm{N} \epsilon \mathrm{dA}$ adduct was detected and it was later established that the presence of this adduct correlates with CYP2E1 expression [161,162]. Interestingly, a significant increase of $\mathrm{N} \epsilon \mathrm{dA}$ was also observed in vitro in CYP2E1 overexpressing HepG2 cells when exposed to 5-25 $\mathrm{mM}$ ethanol [162]. These findings were later also confirmed in esophageal tissue samples [163]. 
A

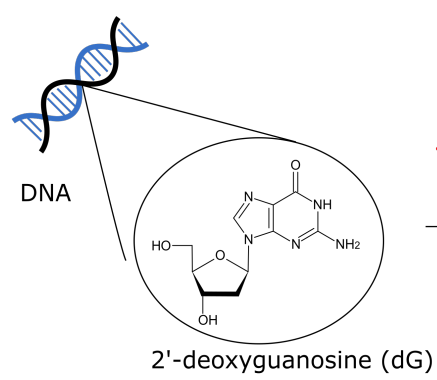

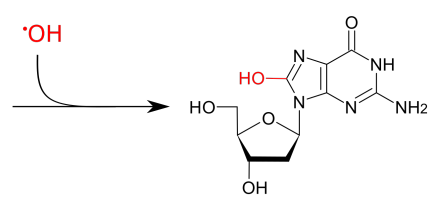

8-hydroxy-2'-dG

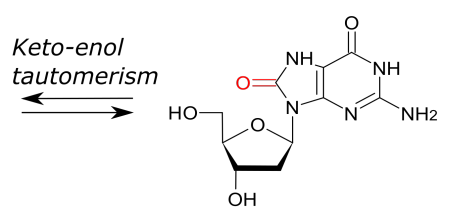

8-oxo-7,8-dihydro-2'-dG

B
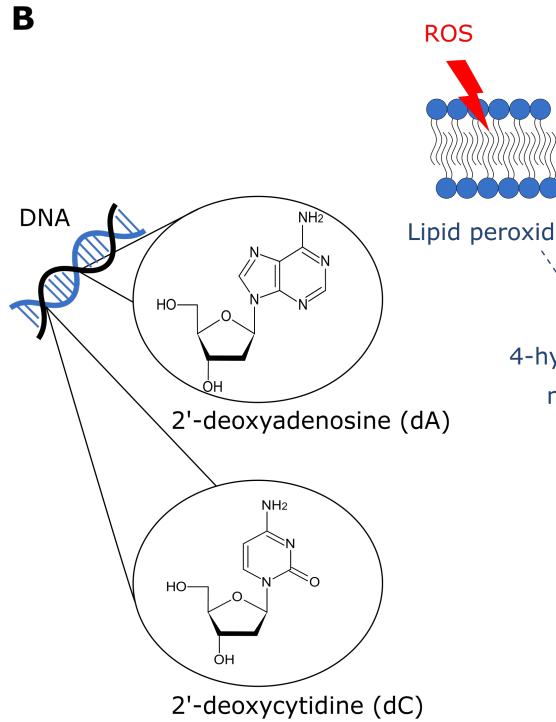

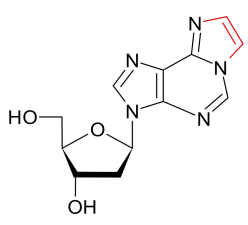

1, $\mathrm{N}^{6}$-etheno-2'-dA

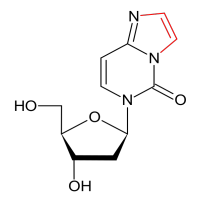

3,N4-etheno-2'-dC

Figure 3. Overview of ROS-derived DNA adducts. There are both direct and indirect effects of ROS on DNA base-pairs. (A) Firstly, a hydroxyl radical can directly affect dG thereby forming 8-hydroxy$2^{\prime}$-dG. Keto-enol tautomerism favors the ketone derivative 8-oxo-7,8-dihydro-2'-dG. (B) On the other hand, ROS can also indirectly lead to DNA adducts via lipid peroxidation which results in formation of 4-HNE and MDA. These aldehydes can interact with DNA base pairs which results in exocyclic etheno adducts. $1, \mathrm{~N}^{6}$-etheno- $2^{\prime}-\mathrm{dA}$ and $3, \mathrm{~N}^{4}$-etheno- $2^{\prime}-\mathrm{dC}$ are visualized in panel $\mathrm{B}$.

\subsection{Ethanol Exposure Alters the Epigenome}

It is very well known that global epigenetic alterations are a hallmark of cancer development [164]. Increasing evidence suggest that ethanol-induced tumorigenesis can also (partially) be explained by epigenetic modifications. Notably, most data have come from research in the liver and the brain [165]. However, these mechanisms might be universal and therefore also affect cells in the oral cavity.

\subsubsection{Ethanol Leads to DNA Hypomethylation}

DNA methylation patterns are important transcriptional controls of gene expression [166]. DNA methylation occurs almost exclusively on carbon 5 of cytosine nucleotides. In a sequence context, often cytosines that precede guanines, so-called CpG dinucleotides, are the target for methylation. $\mathrm{CpG}$ clusters or islands are abundant in promoter regions or regions that contain repetitive DNA sequences [166]. Mostly, methylation in a promoter region is associated with gene silencing. Enzymes that are involved in maintaining methylation patterns are DNA methyltransferases and the most important methyl donor is S-adenosyl-L-methionine (SAM) [166].

Persuasive evidence exists that ethanol can disturb DNA methylation patterns by affecting the one-carbon metabolism, a pathway in which a chemical unit containing one carbon atom (e.g., a methyl group) is transferred from a donor to an acceptor [166]. Ethanol can directly affect key enzymes of the one-carbon metabolism, including methion- 
ine synthase (MTR), methionine adenosyl transferase (MAT), and DNA methyltransferase (DNMT). Ethanol can inhibit MTR and MAT activity which results in reduced SAM levels [167-169]. Indeed in rats fed alcohol for nine weeks, hepatic levels of SAM and DNA methylation fell by about 40\% [170]. DNMT enzyme activity can be inhibited by ethanol and acetaldehyde as well which results in altered DNA methylation patterns [171,172].

Additionally, folate uptake and metabolism are altered in heavy drinkers. In the form of 5-methyltetrahydrofolate, this molecule is involved in the remethylation of homocysteine to methionine, a precursor of SAM [173]. Reduced folate levels have been reported in alcohol abusers which can be due to decreased dietary intake, decreased absorption, or increased urinary excretion [174]. Folate deficiency can reduce SAM levels which consequently affects the DNA methylation capacity of the cells [166,173]. It should however be noted that folate also plays a role in other essential cellular pathways and therefore the link between folate deficiency and malignant transformation is not straightforward [174].

Global DNA hypomethylation has been detected in cancer types with a strong ethanol etiology. Smith et al. for instance detected a global hypomethylation in tissue specimens from head and neck squamous cell carcinomas in contrast to normal mucosa [175]. Tongue squamous cell carcinoma showed a global hypomethylation as well [176]. When performing a multivariate Cox regression analysis on these samples, low $5 \mathrm{mC}$ methylation was significantly associated with poor disease-specific survival [176]. Ethanol-induced DNA hypomethylation can result in the expression of certain oncogenes. For instance, the oncogene Survivin (encoded by BIRC5) is frequently found upregulated in OSCC, probably due to promotor hypomethylation $[177,178]$. Survivin is an inhibitor of apoptosis. When it is expressed, cell death is inhibited which can lead to tumor progression [178]. Additionally, hypomethylation of retrotransposon elements, such as long interspersed elements (LINEs), can influence tumor formation by genome destabilization [179]. LINE-1 hypomethylation was detected in oral rinses of patients diagnosed with OSCC [180]. In accordance, analysis of LINE-1 methylation in OPMDs showed significant hypomethylation in patients where the OPMD progressed into OSCC [181]. This also translated to a worse oral cancer-free survival [181].

On the other hand, promoter hypermethylation can silence tumor suppressor genes thereby promoting carcinogenesis. In oral cancer, promoter hypermethylation of $C D K N 2 A$, CDH1, MGMT, and DAPK1 has been observed [179,181,182].

\subsubsection{Patterns of Histone Modifications Can Change in the Presence of Ethanol}

In addition to DNA methylation, also histone modifications affect transcription, DNA replication and DNA repair [164]. Various modifications are known such as histone acetylation, methylation, phosphorylation, and ubiquitination [165]. These modifications regulate the accessibility of the DNA to e.g., transcription factors. An open chromatin state, i.e., euchromatin, is associated with active gene transcription while heterochromatin is tightly packed and is therefore associated with gene silencing [165].

Ethanol similarly affects histone methylation patterns as DNA methylation discussed in the previous paragraph. Histone methyltransferases also use SAM as a methyl donor and the availability of SAM can be reduced by alcohol abuse. Consequently, histone hypomethylation occurs after chronic ethanol consumption [183]. The exact result of this is uncertain because histone methylation can lead to gene activation as well as deactivation depending on the position of the lysine residue which is modified [183].

In addition, acetylation patterns can be altered by ethanol intake. Histone acetyltransferases (HATs) catalyze histone acetylation whereby acetyl-coenzyme A (acetyl-CoA) is used as an acetyl donor. Histone acetylation typically results in euchromatin, meaning gene activation [183]. It is thought that acetate, produced during the oxidative metabolism of ethanol, can also function as a donor of an acetyl group. Acetate can be converted into acetyl-CoA by acetyl-CoA synthetase [183]. Recently, Mews et al. showed that indeed acetate coming from ethanol metabolism can lead to acetylation in the brain of ethanol-treated mice [184]. It has also been suggested that ethanol can increase histone acetylation through 
modification of HAT activity [185]. Another mechanism whereby ethanol can influence histone acetylation patterns might be through SIRT1 (NAD-dependent protein deacetylase sirtuin-1). SIRT1 is an important sensor that balances transcriptional activation or repression. It has an $\mathrm{NAD}^{+}$-dependent histone deacetylase activity [183]. Ethanol metabolism leads to a lower $\mathrm{NAD}^{+}$/NADH ratio which inhibits SIRT1 and this can interfere with normal acetylation patterns [183]. As the direct action of SIRT1 is histone deacetylation, more histone acetylation is expected in cells exposed to ethanol.

Mancuso et al. studied histone methylation patterns in tissue samples of patients diagnosed with OPMDs or OSCC. In comparison to healthy tissue samples, H3K4 dimethylation was increased while H3K4 trimethylation levels were decreased [186]. Interestingly, Arif et al. also reported histone 3 hyperacetylations on lysine 9 and 14 in both an OSCC cancer cell line and OSCC tissue specimens [187]. In addition, selective acetylation of histone 3 at lysine 9 (H3AcK9) has been attributed to ethanol $[165,188,189]$. It should be noted however this was detected in hepatic and not oral cells. These patterns of altered histone modifications are global changes that can occur throughout the genome. Both H3AcK14 and H3AcK9 have been correlated to active gene expression if these occur in coding regions [190]. If genomic locations of oncogenes are altered, this could potentially contribute to tumorigenesis. Contrarily, less H3K4 trimethylation correlates with a decreased promoter activity [191]. This can also affect oral carcinogenesis if tumor suppressor genes are hit.

\section{Mutational Signatures Give More Insight into Carcinogenesis}

Recently, studying mutational signatures in cancer exomes and genomes gained a lot of attention. Mutations represent a fingerprint of the different mutational processes that have been active over time. Therefore, studying mutational signatures can help to obtain more insight into the molecular mechanisms active during tumorigenesis [192,193]. In addition, discovery of mutational signatures might provide opportunities for new therapies. For example, Ma et al. nicely illustrated that DNA repair deficiencies result in characteristic mutational signatures. This finding can be therapeutically exploited e.g., through implementation of a synthetic lethal (personalized) cancer therapy [194].

'Mutational signatures' are defined as unique combinations of mutation types generated by different mutational processes. Somatic mutations are often divided into four classes: base substitutions, small indels, rearrangements, and copy number changes [192]. These can be further subclassified in biologically meaningful groups. For instance for substitutions, often the type of substitution and the sequence context are taken into account and this results in 96 possible types of mutations [192]. Multiple research groups started to extract mutational signatures from various cancer types and therefore a curated consensus of signatures was needed. The Catalogue of Somatic Mutations in Cancer or COSMIC database provides an excellent overview of the different mutational signatures already extracted [195]. Based on the class of mutations, various mutational signatures are known including single-base substitutions (SBS), doublet base substitutions (DBS), and small insertions-deletions (ID) signatures [195].

Which molecular processes underlie a specific mutational signature is an intriguing question. Somatic mutations may arise from cellular processes [196]. For instance, intrinsic APOBEC (apolipoprotein B mRNA editing enzyme, catalytic polypeptide-like) activity causes a recognizable pattern of mutations (COSMIC signatures SBS2 and SBS13) $[197,198]$. Additionally, exogenous and endogenous mutagens are known to cause specific signatures [196]. Signatures SBS4, DBS2, and ID3 were suggested to be associated with tobacco exposure [198]. Notably, signatures have been linked to specific environmental agents by association studies. Interestingly, a recent investigation by Kucab et al. validated these associations [199]. They sequenced human induced pluripotent stem cells after exposure to various chemicals. There was a striking similarity between the signatures extracted from these in vitro experiments and in vivo association data [199]. Taken together, this 
indicates that mutational signatures extracted from tumor genomes can indeed hint at the underlying mechanisms.

\section{Several Ethanol-Related Mutational Signatures Have Been Identified}

Apart from the mutagens shortly discussed in the previous paragraph, studies have also investigated a link between ethanol consumption and the occurrence of specific mutational signatures in sequencing data derived from tumors. An overview of mutational signatures that have been associated with ethanol is given in Table 1.

Table 1. Overview of ethanol-related mutational signatures discovered in genome sequencing data.

\begin{tabular}{llll}
\hline Signature & Cancer Subsite & Proposed Etiology & References \\
\hline DBS2 & Lung, Head and Neck & Acetaldehyde exposure & {$[199,200]$} \\
SBS16 & Esophagus, Liver & Acetaldehyde exposure & {$[201-203]$} \\
C4 & Liver, Head and Neck, Esophagus, Pancreas & Translesion polymerase $\eta$ & {$[204]$} \\
E6 & Esophagus & Unknown & {$[201]$} \\
\hline
\end{tabular}

As discussed in Section 4.1, acetaldehyde can accumulate in the oral cavity where it can damage the cells. Interestingly, both in vivo and in vitro studies demonstrated that acetaldehyde exposure leads to a characteristic mutational profile, dominated by GG to TT mutations [200]. This specific signature was suggested to be attributable to GG intrastrand crosslinks caused by acetaldehyde [205]. This specific signature is called DBS2 in the COSMIC database [195]. It was identified by Chen et al. in genome sequences of tobaccorelated tumors, such as head and neck cell carcinoma and lung adenocarcinoma [206-208]. Kucab et al. afterwards confirmed that the DBS2 signature is indeed caused by acetaldehyde exposure [199].

Additionally, COSMIC signature SBS16 has been related to ethanol in various types of cancer. Chang et al. identified SBS mutational signatures in genome sequences of esophageal cancer, a cancer type with a strong ethanol etiology. The tumor samples were derived from Chinese patients only, which is important to note as this population has a high frequency of the $A L D H 2 * 2$ allele. In this study, there were six distinct SBS mutational signatures discovered of which several significantly correlated with the alcohol ingestion of the patients [201]. SBS signature E4 was found to be similar to the previously identified SBS16 signature of Alexandrov et al. [196]. Chang et al. also found a correlation between this signature and the presence of $A L D H 2 * 2$ allele, suggesting this signature is linked to acetaldehyde [201]. The results from this research were confirmed by another study in esophageal cancer samples executed by Li et al. [202]. They found a signature, resembling SBS16, which was significantly correlated with alcohol intake and the mutant $A L D H 2 * 2$ allele [202]. In liver cancer, this SBS16 signature was found as well and correlated with alcohol consumption [203]. Computational analysis of exome sequences from The Cancer Genome Atlas (TCGA) HNSCC cohort revealed that the SBS16 signature is in the top five of most commonly detected signatures [209]. Kaplan-Meier graphs also illustrated that patients with a relatively high attribution of SBS16 somatic mutations have a lower overall survival [209].

Interestingly, not all signatures identified in ethanol-related cancers show a link to acetaldehyde. Supek et al. extracted mutational signatures from TCGA data focusing on clustered mutations, defined as mutations in close proximity ( $\leq 500$ base pairs) to each other [204]. Looking at these clustered mutational signatures, the authors identified a signature, C4, characterized by A > G substitutions. This signature was especially prevalent in samples from liver cancer. Signature C4 specifically associated with alcohol consumption and not with other risk factors such as smoking tobacco [204]. The authors hypothesize this ethanol-associated clustered signature arose from the translesion polymerase $\eta$, encoded by the POLH gene [204]. In addition to liver cancer, this C4 signature was also found in head and neck, pancreatic and esophageal cancer. Also in these types of cancer, the C4 
signature was positively associated with alcohol consumption [204]. In addition, the study of Chang et al. discovered more signatures in esophageal cancer samples [201]. There was another SBS signature, called E6, correlating with alcohol drinking but not with acetaldehyde. This signature showed low similarity to any of the COSMIC signatures and therefore they believe it is new signature [201]. Currently, the underlying mechanism of this specific signature is unknown, but it might be interesting for future investigations.

\section{Conclusions and Future Perspectives}

It is clear that heavy alcohol consumption substantially increases the risk for development and malignant transformation of oral neoplasms. Multiple epidemiological association studies and animal studies established the role of ethanol in oral carcinomas and potentially malignant lesions. Despite this clear causal link, the molecular mechanisms underlying this carcinogenic effect of ethanol are still not fully revealed. The metabolites of ethanol, being acetaldehyde and reactive oxygen species, undoubtedly damage mucosal cells by the formation of DNA and protein adducts and DNA crosslinks. Additionally, ethanol is known to alter DNA and histone methylation patterns which can impact cellular survival in case key tumor suppressor genes or oncogenes are affected. However, most of this evidence was obtained from studies in the liver and the brain. An in-depth study of the epigenetic effect of ethanol in oral tissues is currently lacking which may be a proposition for further research.

Ethanol-related mutational signatures confirmed the role of acetaldehyde in esophageal and liver cancer. Nevertheless, other ethanol-related signatures were identified as well of which the mechanisms are currently not fully understood. This might indicate not all carcinogenic mechanisms of ethanol have been identified yet. Notably, there are no reports yet of mutational signatures in oral tumors or potentially malignant lesions which can be pursued in future studies. Discovery of (new) mutational signatures in oral tumors is interesting to determine or confirm underlying molecular mechanisms of ethanol-induced tumorigenesis. Additionally, mutational signatures can discover processes driving tumorigenesis such as DNA repair deficiencies. These processes can be used as a biomarker, but can also result in new therapeutic opportunities.

Author Contributions: All authors contributed to the research, drafting, and editing of this manuscript. All authors have read and agreed to the published version of the manuscript.

Funding: L.H. is a fundamental research PhD fellow at Fonds Wetenschappelijk Onderzoek (FWO), Research Foundation Flanders (11B6720N). She is also partially supported by an FWO project grant (G090618N) obtained by K.J.V. and S.N. R.D. is supported by Emmanuel van der Schueren fellowship for postdoctoral researchers from Kom op tegen Kanker and FWO (1521019N). Research in the laboratory of K.J.V. is supported by VIB, KU Leuven, AB-InBev-Baillet Latour Fund, FWO, VLAIO, and European Research Council (ERC) Consolidator Grant CoG682009.

Institutional Review Board Statement: Not applicable.

Informed Consent Statement: Not applicable.

Conflicts of Interest: The authors declare no conflict of interest.

\section{References}

1. McGovern, P.E.; Zhang, J.; Tang, J.; Zhang, Z.; Hall, G.R.; Moreau, R.A.; Nuñez, A.; Butrym, E.D.; Richards, M.P.; Wang, C.S.; et al. Fermented beverages of pre- and proto-historic China. Proc. Natl. Acad. Sci. USA 2004, 101, 17593-17598. [CrossRef]

2. Hanson, D.J. Historical evolution of alcohol consumption in society. In Alcohol: Science, Policy and Public Health; Boyle, P., Boffetta, P., Lowenfels, A.B., Burns, H., Brawley, O., Eds.; Oxford University Press: Oxford, UK, 2013; pp. 3-13. [CrossRef]

3. Sournia, J.C. A History of Alcoholism, translated ed.; Basil Blackwell: Oxford, UK, 1990; p. 232.

4. Le Daré, B.; Lagente, V.; Gicquel, T. Ethanol and its metabolites: Update on toxicity, benefits, and focus on immunomodulatory effects. Drug Metab. Rev. 2019, 51, 545-561. [CrossRef]

5. $\quad$ Pearl, R. Alcohol and Longevity; Alfred A. Knopf.: New York, NY, USA, 1926; p. 273.

6. Room, R.; Babor, T.; Rehm, J. Alcohol and public health. Lancet 2005, 365, 519-530. [CrossRef] 
7. Griswold, M.G.; Fullman, N.; Hawley, C.; Arian, N.; M Zimsen, S.R.; Tymeson, H.D.; Venkateswaran, V.; Douglas Tapp, A.; Forouzanfar, M.; Salama, J.; et al. Alcohol use and burden for 195 countries and territories, 1990-2016: A systematic analysis for the Global Burden of Disease Study 2016. Lancet 2018, 392, 1015-1035. [CrossRef]

8. World Health Organization. Global Status Report on Alcohol and Health 2018; Technical Report, Licence: CC BY-NC-SA 3.0 IGO; World Health Organization: Geneva, Switzerland, 2018.

9. Rehm, J.; Shield, K.D. Global burden of alcohol use disorders and alcohol liver disease. Biomedicines 2019, 7, 99. [CrossRef]

10. Shield, K.; Manthey, J.; Rylett, M.; Probst, C.; Wettlaufer, A.; Parry, C.D.; Rehm, J. National, regional, and global burdens of disease from 2000 to 2016 attributable to alcohol use: A comparative risk assessment study. Lancet Public Health 2020, 5, e51-e61. [CrossRef]

11. Praud, D.; Rota, M.; Rehm, J.; Shield, K.; Zatoński, W.; Hashibe, M.; La Vecchia, C.; Boffetta, P. Cancer incidence and mortality attributable to alcohol consumption. Int. J. Cancer 2016, 138, 1380-1387. [CrossRef]

12. Rumgay, H.; Shield, K.; Charvat, H.; Ferrari, P.; Sornpaisarn, B.; Obot, I.; Islami, F.; Lemmens, V.E.P.P.; Rehm, J.; Soerjomataram, I. Global burden of cancer in 2020 attributable to alcohol consumption: A population-based study. Lancet Oncol. 2021, 21, S1470-S2045. [CrossRef]

13. International Agency for Research on Cancer. Personal Habits and Indoor Combustions; Technical Report; International Agency for Research on Cancer: Lyon, France, 2012.

14. Shrestha, A.D.; Vedsted, P.; Kallestrup, P.; Neupane, D. Prevalence and incidence of oral cancer in low- and middle-income countries: A scoping review. Eur. J. Cancer Care 2020, 29, e13207. [CrossRef] [PubMed]

15. Johnson, N.W.; Jayasekara, P.; Amarasinghe, A.A.; Hemantha, K. Squamous cell carcinoma and precursor lesions of the oral cavity: Epidemiology and aetiology. Periodontology 2000 2011, 57, 19-37. [CrossRef] [PubMed]

16. Rivera, C. Essentials of oral cancer. Int. J. Clin. Exp. Pathol. 2015, 8, 11884-11894. [PubMed]

17. Bray, F.; Ferlay, J.; Soerjomataram, I.; Siegel, R.L.; Torre, L.A.; Jemal, A. Global cancer statistics 2018: GLOBOCAN estimates of incidence and mortality worldwide for 36 cancers in 185 countries. CA A Cancer J. Clin. 2018, 68, 394-424. [CrossRef] [PubMed]

18. Neville, B.W.; Day, T.A. Oral Cancer and Precancerous Lesions. CA A Cancer J. Clin. 2002, 52, 195-215. [CrossRef]

19. Tanaka, T.; Ishigamori, R. Understanding carcinogenesis for fighting oral cancer. J. Oncol. 2011, 2011, 1-10. [CrossRef] [PubMed]

20. Schwimmer, E. Die idiopathischen Schleim- hautplaques der Mundhöhle (Leukoplakia buc- calis). Arch. Dermatol. Res. 1877, 9,570-611.

21. Speight, P.M.; Khurram, S.A.; Kujan, O. Oral potentially malignant disorders: Risk of progression to malignancy. Oral Surg. Oral Med. Oral Pathol. Oral Radiol. 2018, 125, 612-627. [CrossRef]

22. Pinto, A.C.; Caramês, J.; Francisco, H.; Chen, A.; Azul, A.M.; Marques, D. Malignant transformation rate of oral leukoplakia-Systematic review. Oral Surg. Oral Med. Oral Pathol. Oral Radiol. 2020, 129, 611. [CrossRef]

23. Ganesh, D.; Sreenivasan, P.; Ohman, J.; Wallström, M.; Braz-Silva, P.H.; Giglio, D.; Kjeller, G.; Hasséus, B. Potentially malignant oral disorders and cancer transformation. Anticancer Res. 2018, 38, 3223-3229. [CrossRef]

24. IARC. Tobacco smoking. IARC Monogr. Eval. Carcinog. Risks Chem. Hum. 1986, 38, 35-394.

25. Vineis, P.; Alavanja, M.; Buffler, P.; Fontham, E.; Franceschi, S.; Gao, Y.T.; Gupta, P.C.; Hackshaw, A.; Matos, E.; Samet, J.; et al. Tobacco and Cancer: Recent Epidemiological Evidence. JNCI J. Natl. Cancer Inst. 2004, 96, 99-106. [CrossRef]

26. Boffetta, P.; Hecht, S.; Gray, N.; Gupta, P.; Straif, K. Smokeless tobacco and cancer. Lancet Oncol. 2008, 9, 667-675. [CrossRef]

27. Asthana, S.; Labani, S.; Kailash, U.; Sinha, D.N.; Mehrotra, R. Association of Smokeless Tobacco Use and Oral Cancer: A Systematic Global Review and Meta-Analysis. Nicotine Tob. Res. 2019, 21, 1162-1171. [CrossRef]

28. Siddiqi, K.; Husain, S.; Vidyasagaran, A.; Readshaw, A.; Mishu, M.P.; Sheikh, A. Global burden of disease due to smokeless tobacco consumption in adults: An updated analysis of data from 127 countries. BMC Med. 2020, 18, 1-22. [CrossRef]

29. Ko, Y.; Huang, Y.; Lee, C.; Chen, M.; Lin, L.; Tsai, C. Betel quid chewing, cigarette smoking and alcohol consumption related to oral cancer in Taiwan. J. Oral Pathol. Med. 1995, 24, 450-453. [CrossRef]

30. Hashibe, M.; Brennan, P.; Chuang, S.; Boccia, S.; Castellsague, X.; Chen, C.; Curado, M.; Dal Maso, L.; Daudt, A.; Fabianova, E.; et al. Interaction between tobacco and alcohol use and the risk of head and neck cancer: Pooled analysis in the International Head and Neck Cancer Epidemiology Consortium. Cancer Epidemiol. Biomarkers Prev. 2009, 18, 541-550. [CrossRef] [PubMed]

31. Dal Maso, L.; Torelli, N.; Biancotto, E.; Di Maso, M.; Gini, A.; Franchin, G.; Levi, F.; La Vecchia, C.; Serraino, D.; Polesel, J. Combined effect of tobacco smoking and alcohol drinking in the risk of head and neck cancers: A re-analysis of case-control studies using bi-dimensional spline models. Eur. J. Epidemiol. 2016, 31, 385-393. [CrossRef] [PubMed]

32. Mello, F.; Melo, G.; Pasetto, J.; Silva, C.; Warnakulasuriya, S.; Rivero, E. The synergistic effect of tobacco and alcohol consumption on oral squamous cell carcinoma: A systematic review and meta-analysis. Clin. Oral Investig. 2019, 23, 2849-2859. [CrossRef]

33. Petti, S.; Scully, C. Oral cancer: The association between nation-based alcohol-drinking profiles and oral cancer mortality. Oral Oncol. 2005, 41, 828-834. [CrossRef] [PubMed]

34. Boffetta, P.; Hashibe, M. Alcohol and cancer. Lancet Oncol. 2006, 7, 149-156. [CrossRef]

35. Kanny, D.; Naimi, T.S.; Liu, Y.; Lu, H.; Brewer, R.D. Annual Total Binge Drinks Consumed by U.S. Adults, 2015. Am. J. Prev. Med. 2018, 54, 496. [CrossRef] [PubMed]

36. Melikian, A.; Djordjevic, M.; Hosey, J.; Zhang, J.; Chen, S.; Zang, E.; Muscat, J.; Stellman, S. Gender differences relative to smoking behavior and emissions of toxins from mainstream cigarette smoke. Nicotine Tob. Res. 2007, 9, 377-387. [CrossRef] 
37. Marur, S.; D'Souza, G.; Westra, W.H.; Forastiere, A.A. HPV-associated head and neck cancer: A virus-related cancer epidemic. Lancet Oncol. 2010, 11, 781-789. [CrossRef]

38. Leemans, C.R.; Snijders, P.J.F.; Brakenhoff, R.H. The molecular landscape of head and neck cancer. Nat. Rev. Cancer 2018, 18, 269-282. [CrossRef] [PubMed]

39. Yete, S.; D'Souza, W.; Saranath, D. High-Risk Human Papillomavirus in Oral Cancer: Clinical Implications. Oncology 2018, 94, 133-141. [CrossRef] [PubMed]

40. Nauta, I.H.; Heideman, D.A.M.; Brink, A.; van der Steen, B.; Bloemena, E.; Koljenović, S.; de Jong, R.J.B.; Leemans, C.R.; Brakenhoff, R.H. The unveiled reality of human papillomavirus as risk factor for oral cavity squamous cell carcinoma. Int. J. Cancer 2021, 149, 430. [CrossRef]

41. Khanna, S.; Palackdharry, S.; Roof, L.; Wicker, C.A.; Mark, J.; Zhu, Z.; Jandorav, R.; Molinolo, A.; Takiar, V.; Wise-Draper, T.M. Determining the molecular landscape and impact on prognosis in HPV-associated head and neck cancer. Cancers Head Neck 2020, 5, 11. [CrossRef]

42. Kalinowski, A.; Humphreys, K. Governmental standard drink definitions and low-risk alcohol consumption guidelines in 37 countries. Addiction 2016, 111, 1293-1298. [CrossRef] [PubMed]

43. Hoge Gezondheidsraad. Risico's van Alcoholgebruik HGR NR 9438; Technical Report; Hoge Gezondheidsraad: Brussel, Belgium, 2018.

44. Boffetta, P.; Hashibe, M.; La Vecchia, C.; Zatonski, W.; Rehm, J. The burden of cancer attributable to alcohol drinking. Int. J. Cancer 2006, 119, 884-887. [CrossRef] [PubMed]

45. Baan, R.; Straif, K.; Grosse, Y.; Secretan, B.; El Ghissassi, F.; Bouvard, V.; Altieri, A.; Cogliano, V. Carcinogenicity of alcoholic beverages. Lancet Oncol. 2007, 8, 292-293. [CrossRef]

46. Seitz, H.K.; Stickel, F. Molecular mechanisms of alcohol-mediated carcinogenesis. Nat. Rev. Cancer 2007, 7, 599-612. [CrossRef]

47. Blot, W.J.; McLaughlin, J.K.; Winn, D.M.; Austin, D.F.; Greenberg, R.S.; Susan, S.; Preston, M.; Bernstein, L.; Schoenberg, J.B.; Stemhagen, A.; et al. Smoking and Drinking in Relation to Oral and Pharyngeal Cancer. Cancer Res. 1988, 48, 3282-3287.

48. Yokoyama, A.; Kakiuchi, N.; Yoshizato, T.; Nannya, Y.; Suzuki, H.; Takeuchi, Y.; Shiozawa, Y.; Sato, Y.; Aoki, K.; Kim, S.K.; et al. Age-related remodelling of oesophageal epithelia by mutated cancer drivers. Nature 2019, 565, 312-317. [CrossRef] [PubMed]

49. Hashibe, M.; Brennan, P.; Benhamou, S.; Castellsague, X.; Chen, C.; Curado, M.P.; Dal Maso, L.; Daudt, A.W.; Fabianova, E.; Fernandez, L.; et al. Alcohol drinking in never users of tobacco, cigarette smoking in never drinkers, and the risk of head and neck cancer: Pooled analysis in the International Head and Neck Cancer Epidemiology Consortium. J. Natl. Cancer Inst. 2007, 99, 789. [CrossRef]

50. Polesel, J.; Dal Maso, L.; Bagnardi, V.; Zucchetto, A.; Zambon, A.; Levi, F.; La Vecchia, C.; Franceschi, S. Estimating dose-response relationship between ethanol and risk of cancer using regression spline models. Int. J. Cancer 2005, 114, 836-841. [CrossRef] [PubMed]

51. Goldstein, B.Y.; Chang, S.C.; Hashibe, M.; La Vecchia, C.; Zhang, Z.F. Alcohol consumption and cancers of the oral cavity and pharynx from 1988 to 2009: An update. Eur. J. Cancer Prev. 2010, 19, 431-465. [CrossRef] [PubMed]

52. Turati, F.; Garavello, W.; Tramacere, I.; Bagnardi, V.; Rota, M.; Scotti, L.; Islami, F.; Corrao, G.; Boffetta, P.; La Vecchia, C.; et al. A meta-analysis of alcohol drinking and oral and pharyngeal cancers. Part 2: Results by subsites. Oral Oncol. 2010, 46, 720-726. [CrossRef] [PubMed]

53. Bagnardi, V.; Rota, M.; Botteri, E.; Tramacere, I.; Islami, F.; Fedirko, V.; Scotti, L.; Jenab, M.; Turati, F.; Pasquali, E.; et al. Light alcohol drinking and cancer: A meta-analysis. Ann. Oncol. 2013, 24, 301-308. [CrossRef]

54. Bagnardi, V.; Rota, M.; Botteri, E.; Tramacere, I.; Islami, F.; Fedirko, V.; Scotti, L.; Jenab, M.; Turati, F.; Pasquali, E.; et al. Alcohol consumption and site-specific cancer risk: A comprehensive dose-response meta-analysis. Br. J. Cancer 2015, 112, 580-593. [CrossRef]

55. Di Credico, G.; Polesel, J.; Dal Maso, L.; Pauli, F.; Torelli, N.; Luce, D.; Radoï, L.; Matsuo, K.; Serraino, D.; Brennan, P.; et al. Alcohol drinking and head and neck cancer risk: The joint effect of intensity and duration. Br. J. Cancer 2020, 123, 1456-1463. [CrossRef]

56. Franceschi, S.; Talamini, R.; Barra, S.; Baron, A.E.; Negri, E.; Bidoli, E.; Serraino, D.; La Vecchia, C. Smoking and drinking in relation to cancers of the oral cavity, pharynx, larynx, and esophagus in northern Italy. Cancer Res. 1990, 50, 6502-6507. [CrossRef]

57. Mashberg, A.; Boffetta, P.; Winkelman, R.; Garfinkel, L. Tobacco smoking, alcohol drinking, and cancer of the oral cavity and oropharynx among U.S. veterans. Cancer 1993, 72, 1369-1375. [CrossRef]

58. Balaram, P.; Sridhar, H.; Rajkumar, T.; Vaccarella, S.; Herrero, R.; Nandakumar, A.; Ravichandran, K.; Ramdas, K.; Sankaranarayanan, R.; Gajalakshmi, V.; et al. Oral cancer in Southern India: The influence of smoking, drinking, paanchewing and oral hygiene. Int. J. Cancer 2002, 98, 440-445. [CrossRef] [PubMed]

59. Altieri, A.; Bosetti, C.; Gallus, S.; Franceschi, S.; Dal Maso, L.; Talamini, R.; Levi, F.; Negri, E.; Rodriguez, T.; La Vecchia, C. Wine, beer and spirits and risk of oral and pharyngeal cancer: A case-control study from Italy and Switzerland. Oral Oncol. 2004, 40, 904-909. [CrossRef] [PubMed]

60. Maasland, D.H.; van den Brandt, P.A.; Kremer, B.; Goldbohm, R.A.; Schouten, L.J. Alcohol consumption, cigarette smoking and the risk of subtypes of head-neck cancer: Results from the Netherlands Cohort Study. BMC Cancer 2014, 14, 187. [CrossRef] [PubMed] 
61. Tenore, G.; Nuvoli, A.; Mohsen, A.; Cassoni, A.; Battisti, A.; Terenzi, V.; Monaca, M.D.; Raponi, I.; Brauner, E.; De Felice, F.; et al. Tobacco, alcohol and family history of cancer as risk factors of Oral Squamous Cell Carcinoma: Case-control retrospective study. Appl. Sci. (Switz.) 2020, 10, 3896. [CrossRef]

62. Sarich, P.; Canfell, K.; Egger, S.; Banks, E.; Joshy, G.; Grogan, P.; Weber, M.F. Alcohol consumption, drinking patterns and cancer incidence in an Australian cohort of 226,162 participants aged 45 years and over. Br. J. Cancer 2021, 124, 513-523. [CrossRef]

63. Znaori, A.; Brennan, P.; Gajalakshmi, V.; Mathew, A.; Shanta, V.; Varghese, C.; Boffetta, P. Independent and combined effects of tobacco smoking, chewing and alcohol drinking on the risk of oral, pharyngeal and esophageal cancers in Indian men. Int. J. Cancer 2003, 105, 681-686. [CrossRef]

64. Moreno-López, L.A.; Esparza-Gómez, G.C.; González-Navarro, A.; Cerero-Lapiedra, R.; González-Hernández, M.J.; Domínguez-Rojas, V. Risk of oral cancer associated with tobacco smoking, alcohol consumption and oral hygiene: A case-control study in Madrid, Spain. Oral Oncol. 2000, 36, 170-174. [CrossRef]

65. Moore, S.R.; Johnson, N.W.; Pierce, A.M.; Wilson, D.F. The epidemiology of lip cancer: A review of global incidence and aetiology. Oral Dis. 1999, 5, 185-195. [CrossRef]

66. López, E.P.M.; Moral, R.M.M.d.; Martínez-García, C.; Zanetti, R.; Rosso, S.; Serrano, S.; Aneiros, J.F.; Jimenez-Puente, A.; Redondo, M. Lifestyles, environmental and phenotypic factors associated with lip cancer: A case-control study in southern Spain. Br. J. Cancer 2003, 88, 1702-1707. [CrossRef] [PubMed]

67. Lin, W.J.; Jiang, R.S.; Wu, S.H.; Chen, F.J.; Liu, S.A. Smoking, alcohol, and betel quid and oral cancer: A prospective cohort study. J. Oncol. 2011, 2011, 525976. [CrossRef]

68. Anantharaman, D.; Marron, M.; Lagiou, P.; Samoli, E.; Ahrens, W.; Pohlabeln, H.; Slamova, A.; Schejbalova, M.; Merletti, F.; Richiardi, L.; et al. Population attributable risk of tobacco and alcohol for upper aerodigestive tract cancer. Oral Oncol. 2011, 47, 725-731. [CrossRef]

69. Ferreira Antunes, J.; Toporcov, T.; Biazevic, M.; Boing, A.; Scully, C.; Petti, S. Joint and independent effects of alcohol drinking and tobacco smoking on oral cancer: A large case-control study. PLoS ONE 2013, 8, e68132. [CrossRef]

70. Wight, A.J.; Ogden, G.R. Possible mechanisms by which alcohol may influence the development of oral cancer-A review. Oral Oncol. 1998, 34, 441-447. [CrossRef]

71. Maserejian, N.N.; Joshipura, K.J.; Rosner, B.A.; Giovannucci, E.; Zavras, A.I. Prospective study of alcohol consumption and risk of oral premalignant lesions in men. Cancer Epidemiol. Biomarkers Prev. 2006, 15, 774-781. [CrossRef]

72. Li, L.; Psoter, W.J.; Buxó, C.J.; Elias, A.; Cuadrado, L.; Morse, D.E. Smoking and drinking in relation to oral potentially malignant disorders in Puerto Rico: A case-control study. BMC Cancer 2011, 11, 324. [CrossRef]

73. Kumar, S.; Debnath, N.; Ismail, M.B.; Kumar, A.; Kumar, A.; Badiyani, B.K.; Dubey, P.K.; Sukhtankar, L.V. Prevalence and Risk Factors for Oral Potentially Malignant Disorders in Indian Population. Adv. Prev. Med. 2015, 2015, 1-7. [CrossRef]

74. Chher, T.; Hak, S.; Kallarakkal, T.G.; Durward, C.; Ramanathan, A.; Ghani, W.M.N.; Razak, I.A.; Harun, M.H.; Ashar, N.A.M.; Rajandram, R.K.; et al. Prevalence of oral cancer, oral potentially malignant disorders and other oral mucosal lesions in Cambodia. Ethn. Health 2018, 23, 1-15. [CrossRef] [PubMed]

75. Aghbari, S.M.H.; Abushouk, A.I.; Attia, A.; Elmaraezy, A.; Menshawy, A.; Ahmed, M.S.; Elsaadany, B.A.; Ahmed, E.M. Malignant transformation of oral lichen planus and oral lichenoid lesions: A meta-analysis of 20095 patient data. Oral Oncol. 2017, 68, 92-102. [CrossRef] [PubMed]

76. González-Moles, M.Á.; Ruiz-Ávila, I.; González-Ruiz, L.; Ayén, Á.; Gil-Montoya, J.A.; Ramos-García, P. Malignant transformation risk of oral lichen planus: A systematic review and comprehensive meta-analysis. Oral Oncol. 2019, 96, 121-130. [CrossRef] [PubMed]

77. Idrees, M.; Kujan, O.; Shearston, K.; Farah, C.S. Oral lichen planus has a very low malignant transformation rate: A systematic review and meta-analysis using strict diagnostic and inclusion criteria. J. Oral Pathol. Med. 2020, 1-12. [CrossRef]

78. Smith, G.D.; Ebrahim, S. 'Mendelian randomization': Can genetic epidemiology contribute to understanding environmental determinants of disease? Int. J. Epidemiol. 2003, 32, 1-22. [CrossRef]

79. Luczak, S.E.; Glatt, S.J.; Wall, T.J. Meta-analyses of ALDH2 and ADH1B with alcohol dependence in asians. Psychol. Bull. 2006, 132, 607-621. [CrossRef] [PubMed]

80. Hasin, D.; Aharonovich, E.; Liu, X.; Mamman, Z.; Matseoane, K.; Carr, L.; Li, T.K. Alcohol and ADH2 in Israel: Ashkenazis, Sephardics, and recent Russian immigrants. Am. J. Psychiatry 2002, 159, 1432-1434. [CrossRef]

81. Liu, M.; Jiang, Y.; Wedow, R.; Li, Y.; Brazel, D.M.; Chen, F.; Datta, G.; Davila-Velderrain, J.; McGuire, D.; Tian, C.; et al. Association studies of up to 1.2 million individuals yield new insights into the genetic etiology of tobacco and alcohol use. Nat. Genet. 2019, 51, 237-244. [CrossRef]

82. Gormley, M.; Dudding, T.; Sanderson, E.; Martin, R.M.; Thomas, S.; Tyrrell, J.; Ness, A.R.; Brennan, P.; Munafò, M.; Pring, M.; et al. A multivariable Mendelian randomization analysis investigating smoking and alcohol consumption in oral and oropharyngeal cancer. Nat. Commun. 2020, 11, 1-10. [CrossRef]

83. Tang, X.H.; Knudsen, B.; Bemis, D.; Tickoo, S.; Gudas, L.J. Oral Cavity and Esophageal Carcinogenesis Modeled in CarcinogenTreated Mice. Clin. Cancer Res. 2004, 10, 301-313. [CrossRef] [PubMed]

84. Guo, Y.; Wang, X.; Zhang, X.; Sun, Z.; Chen, X. Ethanol Promotes Chemically Induced Oral Cancer in Mice through Activation of the 5-Lipoxygenase Pathway of Arachidonic Acid Metabolism. Cancer Prev. Res. 2011, 4, 1863-1872. [CrossRef] 
85. Nachiappan, V.; Mufti, S.I.; Chakravarti, A.; Eskelson, C.D.; Rajasekharan, R. Lipid peroxidation and ethanol-related tumor promotion in Fischer-344 rats treated with tobacco-specific nitrosamines. Alcohol Alcohol. 1994, 29, 565-574.

86. Soffritti, M.; Belpoggi, F.; Cevolani, D.; Guarino, M.; Padovani, M.; Maltoni, C. Results of Long-Term Experimental Studies on the Carcinogenicity of Methyl Alcohol and Ethyl Alcohol in Rats. Ann. N. Y. Acad. Sci. 2002, 982, 46-69. [CrossRef] [PubMed]

87. Müller, P.; Hepke, B.; Meldau, U.; Raabe, G. Tissue damage in the rabbit oral mucosa by acute and chronic direct toxic action of different alcohol concentrations. Exp. Pathol. 1983, 24, 171-181. [CrossRef]

88. Reidy, J.; McHugh, E.; Stassen, L.F. A review of the relationship between alcohol and oral cancer. Surgeon 2011, 9, 278-283. [CrossRef]

89. Garcia Martins, R.H.; Marques Madeira, S.L.; Fabro, A.T.; Rocha, N.D.S.; De Oliveira Semenzati, G.; Alves, K.F. Effects to exposure of tobacco smoke and alcohol on the tongue and pharynx of rats. Inhal. Toxicol. 2012, 24, 153-160. [CrossRef]

90. Wu, D.; Cederbaum, A.I. Alcohol, oxidative stress, and free radical damage. Alcohol Res. Health 2003, 27, 277-284. [CrossRef] [PubMed]

91. Bailey, S.M.; Cunningham, C.C. Contribution of mitochondria to oxidative stress associated with alcoholic liver disease. Free Radic. Biol. Med. 2002, 32, 11-16. [CrossRef]

92. Crabb, D.W.; Matsumoto, M.; Chang, D.; You, M. Overview of the role of alcohol dehydrogenase and aldehyde dehydrogenase and their variants in the genesis of alcohol-related pathology. Proc. Nutr. Soc. 2004, 63, 49-63. [CrossRef] [PubMed]

93. Edenberg, H.J. The genetics of alcohol metabolism: Role of alcohol dehydrogenase and aldehyde dehydrogenase variants. Alcohol Res. Health 2007, 30, 5-13.

94. Vondracek, M.; Xi, Z.; Larsson, P.; Baker, V.; Mace, K.; Pfeifer, A.; Tjälve, H.; Donato, M.T.; Gomez-Lechon, M.J.; Graftström, R.C. Cytochrome P450 expression and related metabolism in human buccal mucosa. Carcinogenesis 2001, 22, 481-488. [CrossRef]

95. Muto, M.; Hitomi, Y.; Ohtsu, A.; Shimada, H.; Kashiwase, Y.; Sasaki, H.; Yoshida, S.; Esumi, H. Acetaldehyde production by non-pathogenic Neisseria in human oral microflora: Implications for carcinogenesis in upper aerodigestive tract. Int. J. Cancer 2000, 88, 342-350. [CrossRef]

96. Kurkivuori, J.; Salaspuro, V.; Kaihovaara, P.; Kari, K.; Rautemaa, R.; Grönroos, L.; Meurman, J.H.; Salaspuro, M. Acetaldehyde production from ethanol by oral streptococci. Oral Oncol. 2007, 43, 181-186. [CrossRef]

97. Moritani, K.; Takeshita, T.; Shibata, Y.; Ninomiya, T.; Kiyohara, Y.; Yamashita, Y. Acetaldehyde production by major oral microbes. Oral Dis. 2015, 21, 748-754. [CrossRef]

98. Homann, N.; Jousimies-Somer, H.; Jokelainen, K.; Heine, R.; Salaspuro, M. High acetaldehyde levels in saliva after ethanol consumption: methodological aspects and pathogenetic implications. Carcinogenesis 1997, 18, 1743. [CrossRef] [PubMed]

99. Salaspuro, V.; Salaspuro, M. Synergistic effect of alcohol drinking and smoking on in vivo acetaldehyde concentration in saliva. Int. J. Cancer 2004, 111, 480-483. [CrossRef] [PubMed]

100. Lachenmeier, D.W.; Sohnius, E.M. The role of acetaldehyde outside ethanol metabolism in the carcinogenicity of alcoholic beverages: Evidence from a large chemical survey. Food Chem. Toxicol. 2008, 46, 2903-2911. [CrossRef]

101. Balbo, S.; Brooks, P.J. Implications of Acetaldehyde-Derived DNA Adducts for Understanding Alcohol-Related Carcinogenesis. In Biological Basis of Alcohol-Induced Cancer. Advances in Experimental Medicine and Biology; Vasiliou, V., Zakhari, S., Seitz, H., Hoek, J., Eds.; Springer New York LLC: New York, NY, USA, 2015; Volume 815, pp. 71-88. [CrossRef]

102. Homann, N.; Tillonen, J.; Meurman, J.H.; Rintamäki, H.; Lindqvist, C.; Rautio, M.; Jousimies-Somer, H.; Salaspuro, M. Increased salivary acetaldehyde levels in heavy drinkers and smokers: A microbiological approach to oral cavity cancer. Carcinogenesis 2000, 21, 663-668. [CrossRef] [PubMed]

103. Fan, X.; Peters, B.A.; Jacobs, E.J.; Gapstur, S.M.; Purdue, M.P.; Freedman, N.D.; Alekseyenko, A.V.; Wu, J.; Yang, L.; Pei, Z.; et al. Drinking alcohol is associated with variation in the human oral microbiome in a large study of American adults. Microbiome 2018, 6. [CrossRef]

104. Zakhari, S. Overview: How is alcohol metabolized by the body? Alcohol Res. Health 2006, 29, $245-254$.

105. Lieber, C.S.; DeCarli, L.M. Hepatic microsomal ethanol-oxidizing system. In vitro characteristics and adaptive properties in vivo. J. Biol. Chem. 1970, 245, 2512. [CrossRef]

106. Salmela, K.S.; Kessova, I.G.; Tsyrlov, I.B.; Lieber, C.S. Respective Roles of Human Cytochrome P-4502E1, 1A2, and 3A4 in the Hepatic Microsomal Ethanol Oxidizing System. Alcohol. Clin. Exp. Res. 1998, 22, 2125-2132. [CrossRef]

107. Lieber, C.S. The discovery of the microsomal ethanol oxidizing system and its physiologic and pathologic role. Drug Metab. Rev. 2004, 36, 511-529. [CrossRef]

108. Lieber, C.S.; Decarli, L.M. The role of the hepatic microsomal ethanol oxidizing system (MEOS) for ethanol metabolism in vivo. J. Pharmacol. Exp. Ther. 1972, 181, 279-2887.

109. Oneta, C.M.; Lieber, C.S.; Li, J.J.; Rüttimann, S.; Schmid, B.; Lattmann, J.; Rosman, A.S.; Seitz, H.K. Dynamics of cytochrome P4502E1 activity in man: Induction by ethanol and disappearance during withdrawal phase. J. Hepatol. 2002, 36, 47-52. [CrossRef]

110. Kubiak-Tomaszewska, G.; Tomaszewski, P.; Pachecka, J.; Struga, M.; Olejarz, W.; Mielczarek-Puta, M.; Nowicka, G. Molecular mechanisms of ethanol biotransformation: Enzymes of oxidative and nonoxidative metabolic pathways in human. Xenobiotica 2020, 50, 1180-1201. [CrossRef] [PubMed]

111. Goyal, M.M.; Basak, A. Hydroxyl radical generation theory: A possible explanation of unexplained actions of mammalian catalase. Int. J. Biochem. Mol. Biol. 2012, 3, 289. [CrossRef] 
112. Aragon, C.M.; Rogan, F.; Amit, Z. Ethanol metabolism in rat brain homogenates by a catalase-H2O2 system. Biochem. Pharmacol. 1992, 44, 93-98. [CrossRef]

113. Zimatkin, S.M.; Pronko, S.P.; Vasiliou, V.; Gonzalez, F.J.; Deitrich, R.A. Enzymatic mechanisms of ethanol oxidation in the brain. Alcohol. Clin. Exp. Res. 2006, 30, 1500-1505. [CrossRef] [PubMed]

114. Fang, J.L.; Vaca, C.E. Detection of DNA adducts of acetaldehyde in peripheral white blood cells of alcohol abusers. Carcinogenesis 1997, 18, 627-632. [CrossRef] [PubMed]

115. Wang, M.; McIntee, E.J.; Cheng, G.; Shi, Y.; Villalta, P.W.; Hecht, S.S. Identification of DNA adducts of acetaldehyde. Chem. Res. Toxicol. 2000, 13, 1149-1157. [CrossRef]

116. Perrino, F.W.; Blans, P.; Harvey, S.; Gelhaus, S.L.; McGrath, C.; Akman, S.A.; Jenkins, G.S.; LaCourse, W.R.; Fishbein, J.C. The $\mathrm{N}^{2}$-Ethylguanine and the $\mathrm{O}^{6}$-Ethyl- and $\mathrm{O}^{6}$-Methylguanine Lesions in DNA: Contrasting Responses from the "Bypass" DNA Polymerase $\eta$ and the Replicative DNA Polymerase $\alpha$. Chem. Res. Toxicol. 2003, 16, 1616-1623. [CrossRef]

117. Choi, J.Y.; Guengerich, F.P. Adduct size limits efficient and error-free bypass across bulky $\mathrm{N}^{2}$-guanine DNA lesions by human DNA polymerase $\eta$. J. Mol. Biol. 2005, 352, 72-90. [CrossRef] [PubMed]

118. Upton, D.C.; Wang, X.; Blans, P.; Perrino, F.W.; Fishbein, J.C.; Akman, S.A. Replication of $\mathrm{N}^{2}$-ethyldeoxyguanosine DNA adducts in the human embryonic kidney cell line 293. Chem. Res. Toxicol. 2006, 19, 960-967. [CrossRef]

119. Theruvathu, J.A.; Jaruga, P.; Nath, R.G.; Dizdaroglu, M.; Brooks, P.J. Polyamines stimulate the formation of mutagenic 1, $\mathrm{N}^{2}$ propanodeoxyguanosine adducts from acetaldehyde. Nucleic Acids Res. 2005, 33, 3520. [CrossRef]

120. Garcia, C.C.M.; Angeli, J.P.F.; Freitas, F.P.; Gomes, O.F.; De Oliveira, T.F.; Loureiro, A.P.M.; Di Mascio, P.; Medeiros, M.H. [13C2]-acetaldehyde promotes unequivocal formation of $1, \mathrm{~N}^{2}$-propano-2'-deoxyguanosine in human cells. J. Am. Chem. Soc. 2011, 133, 9140-9143. [CrossRef] [PubMed]

121. Brooks, P.J.; Zakhari, S. Acetaldehyde and the genome: Beyond nuclear DNA adducts and carcinogenesis. Environ. Mol. Mutagen. 2014, 55, 77-91. [CrossRef]

122. Yang, I.Y.; Hossain, M.; Miller, H.; Khullar, S.; Johnson, F.; Grollman, A.; Moriya, M. Responses to the Major Acrolein-derived Deoxyguanosine Adduct in Escherichia coli. J. Biol. Chem. 2001, 276, 9071-9076. [CrossRef] [PubMed]

123. Minko, I.G.; Washington, M.T.; Kanuri, M.; Prakash, L.; Prakash, S.; Lloyd, R.S. Translesion synthesis past acrolein-derived DNA adduct, $\gamma$-hydroxypropanodeoxyguanosine, by yeast and human DNA polymerase $\eta$. J. Biol. Chem. 2003, 278, 784-790. [CrossRef] [PubMed]

124. Langevin, F.; Crossan, G.P.; Rosado, I.V.; Arends, M.J.; Patel, K.J. Fancd2 counteracts the toxic effects of naturally produced aldehydes in mice. Nature 2011, 475, 53-59. [CrossRef] [PubMed]

125. Garaycoechea, J.I.; Crossan, G.P.; Langevin, F.; Mulderrig, L.; Louzada, S.; Yang, F.; Guilbaud, G.; Park, N.; Roerink, S.; Nik-Zainal, S.; et al. Alcohol and endogenous aldehydes damage chromosomes and mutate stem cells. Nature 2018, 553, 171-177. [CrossRef] [PubMed]

126. Tacconi, E.M.; Lai, X.; Folio, C.; Porru, M.; Zonderland, G.; Badie, S.; Michl, J.; Sechi, I.; Rogier, M.; Matía García, V.; et al. BRCA 1 and BRCA 2 tumor suppressors protect against endogenous acetaldehyde toxicity. EMBO Mol. Med. 2017, 9, 1398-1414. [CrossRef]

127. Kim, H.; D’Andrea, A.D. Regulation of DNA cross-link repair by the Fanconi anemia/BRCA pathway. Genes Dev. 2012, 26, 1393-1408. [CrossRef]

128. Hodskinson, M.R.; Bolner, A.; Sato, K.; Kamimae-Lanning, A.N.; Rooijers, K.; Witte, M.; Mahesh, M.; Silhan, J.; Petek, M.; Williams, D.M.; et al. Alcohol-derived DNA crosslinks are repaired by two distinct mechanisms. Nature 2020, 579, 603-608. [CrossRef] [PubMed]

129. Loureiro, A.P.M.; Di Mascio, P.; Gomes, O.F.; Medeiros, M.H. trans,trans-2,4-Decadienal-induced 1,N2-etheno-2'-deoxyguanosine adduct formation. Chem. Res. Toxicol. 2000, 13, 601-609. [CrossRef] [PubMed]

130. Choi, J.Y.; Zang, H.; Angel, K.C.; Kozekov, I.D.; Goodenough, A.K.; Rizzo, C.J.; Guengerich, F.P. Translesion synthesis across 1,N2-ethenoguanine by human DNA polymerases. Chem. Res. Toxicol. 2006, 19, 879-886. [CrossRef]

131. Thelen, A.Z.; O'Brien, P.J. Recognition of 1,N2-ethenoguanine by alkyladenine DNA glycosylase is restricted by a conserved active-site residue. J. Biol. Chem. 2020, 295, 1685-1693. [CrossRef]

132. Balbo, S.; Juanes, R.C.; Khariwala, S.; Baker, E.J.; Daunais, J.B.; Grant, K.A. Increased levels of the acetaldehyde-derived DNA adduct N2-ethyldeoxyguanosine in oral mucosa DNA from Rhesus monkeys exposed to alcohol. Mutagenesis 2016, 31, 553-558. [CrossRef] [PubMed]

133. Yukawa, Y.; Ohashi, S.; Amanuma, Y.; Nakai, Y.; Tsurumaki, M.; Kikuchi, O.; Miyamoto, S.; Oyama, T.; Kawamoto, T.; Chiba, T.; et al. Impairment of aldehyde dehydrogenase 2 increases accumulation of acetaldehyde-derived DNA damage in the esophagus after ethanol ingestion. Am. J. Cancer Res. 2014, 4, 279-284.

134. Balbo, S.; Meng, L.; Bliss, R.L.; Jensen, J.A.; Hatsukami, D.K.; Hecht, S.S. Kinetics of DNA adduct formation in the oral cavity after drinking alcohol. Cancer Epidemiol. Biomarkers Prev. 2012, 21, 601-608. [CrossRef]

135. Matsuda, T.; Yabushita, H.; Kanaly, R.A.; Shibutani, S.; Yokoyama, A. Increased DNA damage in ALDH2-deficient alcoholics. Chem. Res. Toxicol. 2006, 19, 1374-1378. [CrossRef]

136. Wu, D.; Cederbaum, A.I. Oxidative stress and alcoholic liver disease. Semin. Liver Dis. 2009, 29, 141-154. [CrossRef] [PubMed]

137. Kesarwala, A.; Krishna, M.; Mitchell, J. Oxidative stress in oral diseases. Oral Dis. 2016, 22, 9-18. [CrossRef]

138. Enwonwu, C.O.; Meeks, V.I. Bionutrition and oral cancer in humans. Crit. Rev. Oral Biol. Med. 1995, 6, 5-17. [CrossRef] 
139. Irie, K.; Tomofuji, T.; Tamaki, N.; Sanbe, T.; Ekuni, D.; Azuma, T.; Maruyama, T.; Yamamoto, T. Effects of ethanol consumption on periodontal inflammation in rats. J. Dent. Res. 2008, 87, 456-460. [CrossRef]

140. Cadet, J.; Richard Wagner, J. DNA base damage by reactive oxygen species, oxidizing agents, and UV radiation. Cold Spring Harb. Perspect. Biol. 2013, 5, a012559. [CrossRef]

141. Valavanidis, A.; Vlachogianni, T.; Fiotakis, C. 8-Hydroxy-2'-deoxyguanosine (8-OHdG): A critical biomarker of oxidative stress and carcinogenesis. J. Environ. Sci. Health Part C Environ. Carcinog. Ecotoxicol. Rev. 2009, 27, 120-139. [CrossRef]

142. Cheng, K.C.; Cahill, D.S.; Kasai, H.; Nishimura, S.; Loeb, L.A. 8-Hydroxyguanine, an abundant form of oxidative DNA damage, causes $\mathrm{G} \rightarrow \mathrm{T}$ and $\mathrm{A} \rightarrow \mathrm{C}$ substitutions. J. Biol. Chem. 1992, 267, 166-172. [CrossRef]

143. Jaiswal, M.; LaRusso, N.F.; Nishioka, N.; Nakabeppu, Y.; Gores, G.J. Human Ogg1, a Protein Involved in the Repair of 8-Oxoguanine, Is Inhibited by Nitric Oxide. Cancer Res. 2001, 61, 6388-6393. [PubMed]

144. Deng, X.S.; Deitrich, R. Ethanol Metabolism and Effects: Nitric Oxide and its Interaction. Curr. Clin. Pharmacol. 2007, 2, 145-153. [CrossRef]

145. Valko, M.; Leibfritz, D.; Moncol, J.; Cronin, M.T.; Mazur, M.; Telser, J. Free radicals and antioxidants in normal physiological functions and human disease. Int. J. Biochem. Cell Biol. 2007, 39, 44-84. [CrossRef] [PubMed]

146. Niemela, O. Distribution of ethanol-induced protein adducts in vivo: Relationship to tissue injury. Free Radic. Biol. Med. 2001, 31, 1533-1538. [CrossRef]

147. Ghissassi, F.E.; Barbin, A.; Nair, J.; Bartsch, H. Formation of $1, \mathrm{~N}^{6}$-Ethenoadenine and $3, \mathrm{~N}^{4}$-Ethenocytosine by Lipid Peroxidation Products and Nucleic Acid Bases. Chem. Res. Toxicol. 1995, 8, 278-283. [CrossRef]

148. O'Brien, P.J.; Ellenberger, T. Dissecting the Broad Substrate Specificity of Human 3-Methyladenine-DNA Glycosylase. J. Biol. Chem. 2004, 279, 9750-9757. [CrossRef]

149. Kavli, B.; Sundheim, O.; Akbari, M.; Otterlei, M.; Nilsen, H.; Skorpen, F.; Aas, P.A.; Hagen, L.; Krokan, H.E.; Slupphaug, G. hUNG2 is the major repair enzyme for removal of uracil from U:A matches, U:G mismatches, and U in single-stranded DNA, with hSMUG1 as a broad specificity backup. J. Biol. Chem. 2002, 277, 39926-39936. [CrossRef]

150. Goto, M.; Shinmura, K.; Matsushima, Y.; Ishino, K.; Yamada, H.; Totsuka, Y.; Matsuda, T.; Nakagama, H.; Sugimura, H. Human DNA glycosylase enzyme TDG repairs thymine mispaired with exocyclic etheno-DNA adducts. Free Radic. Biol. Med. 2014, 76, 136-146. [CrossRef]

151. Linhart, K.; Bartsch, H.; Seitz, H.K. The role of reactive oxygen species (ROS) and cytochrome P-450 2E1 in the generation of carcinogenic etheno-DNA adducts. Redox Biol. 2014, 3, 56-62. [CrossRef]

152. Hu, W.; Feng, Z.; Eveleigh, J.; Iyer, G.; Pan, J.; Amin, S.; Chung, F.L.; Tang, M.S. The major lipid peroxidation product, trans4-hydroxy-2-nonenal, preferentially forms DNA adducts at codon 249 of human p53 gene, a unique mutational hotspot in hepatocellular carcinoma. Carcinogenesis 2002, 23, 1789. [CrossRef]

153. Cederbaum, A.I.; Lu, Y.; Wu, D. Role of oxidative stress in alcohol-induced liver injury. Arch. Toxicol. 2009, 83, 519-548. [CrossRef]

154. Tuma, D.J.; Casey, C.A. Dangerous byproducts of alcohol breakdown-Focus on adducts. Alcohol Res. Health 2003, 27, 285-290. [PubMed]

155. Feller, L.; Altini, M.; Lemmer, J. Inflammation in the context of oral cancer. Oral Oncol. 2013, 49, 887-892. [CrossRef] [PubMed]

156. Hirano, T. Alcohol consumption and oxidative DNA damage. Int. J. Environ. Res. Public Health 2011, 8, 2895-2906. [CrossRef] [PubMed]

157. Fagundes, N.C.F.; Fernandes, L.M.P.; Paraense, R.S.D.O.; De Farias-Junior, P.M.A.; Teixeira, F.B.; Alves, S.M.; Pinheiro, J.D.J.V.; Crespo-López, M.E.; Maia, C.S.F.; Lima, R.R. Binge Drinking of Ethanol during Adolescence Induces Oxidative Damage and Morphological Changes in Salivary Glands of Female Rats. Oxid. Med. Cell. Longev. 2016, 2016, 7323627. [CrossRef]

158. Urvalek, A.M.; Osei-Sarfo, K.; Tang, X.H.; Zhang, T.; Scognamiglio, T.; Gudas, L.J. Identification of Ethanol and 4-Nitroquinoline1-Oxide Induced Epigenetic and Oxidative Stress Markers During Oral Cavity Carcinogenesis. Alcohol. Clin. Exp. Res. 2015, 39, 1360-1372. [CrossRef]

159. Kaur, J.; Politis, C.; Jacobs, R. Salivary 8-hydroxy-2-deoxyguanosine, malondialdehyde, vitamin C, and vitamin E in oral pre-cancer and cancer: Diagnostic value and free radical mechanism of action. Clin. Oral Investig. 2016, 20, 315-319. [CrossRef] [PubMed]

160. Warnakulasuriya, S.; Parkkila, S.; Nagao, T.; Preedy, V.R.; Pasanen, M.; Koivisto, H.; Niemelä, O. Demonstration of ethanolinduced protein adducts in oral leukoplakia (pre-cancer) and cancer. J. Oral Pathol. Med. 2008, 37, 157-165. [CrossRef] [PubMed]

161. Frank, A.; Seitz, H.K.; Bartsch, H.; Frank, N.; Nair, J. Immunohistochemical detection of 1, N6-ethenodeoxyadenosine in nuclei of human liver affected by disease predisposing to hepato-carcinogenesis. Carcinogenesis 2004, 25, 1027-1031. [CrossRef]

162. Wang, Y.; Millonig, G.; Nair, J.; Patsenker, E.; Stickel, F.; Mueller, S.; Bartsch, H.; Seitz, H.K. Ethanol-induced cytochrome P4502E1 causes carcinogenic etheno-DNA lesions in alcoholic liver disease. Hepatology 2009, 50, 453-461. [CrossRef]

163. Millonig, G.; Wang, Y.; Homann, N.; Bernhardt, F.; Qin, H.; Mueller, S.; Bartsch, H.; Seitz, H.K. Ethanol-mediated carcinogenesis in the human esophagus implicates CYP2E1 induction and the generation of carcinogenic DNA-lesions. Int. J. Cancer 2011, 128, 533-540. [CrossRef] [PubMed]

164. Sharma, S.; Kelly, T.K.; Jones, P.A. Epigenetics in cancer. Carcinogenesis 2010, 31, 27-36. [CrossRef]

165. Shukla, S.D.; Velazquez, J.; French, S.W.; Lu, S.C.; Ticku, M.K.; Zakhari, S. Emerging role of epigenetics in the actions of alcohol. Alcohol. Clin. Exp. Res. 2008, 32, 1525-1534. [CrossRef] 
166. Varela-Rey, M.; Woodhoo, A.; Martinez-Chantar, M.L.; Mato, J.M.; Lu, S.C. Alcohol, DNA methylation, and cancer. Alcohol Res. Curr. Rev. 2012, 35, 25-35.

167. Barak, A.J.; Beckenhauer, H.C.; Tuma, D.J. Betaine effects on hepatic methionine metabolism elicited by short-term ethanol feeding. Alcohol 1996, 13, 483-486. [CrossRef]

168. Sánchez-Góngora, E.; Ruiz, F.; Mingorance, J.; An, W.; Corrales, F.J.; Mato, J.M. Interaction of liver methionine adenosyltransferase with hydroxyl radical. FASEB J. 1997, 11, 1013-1019. [CrossRef] [PubMed]

169. Ruiz, F.; Corrales, F.J.; Miqueo, C.; Mato, J.M. Nitric oxide inactivates rat hepatic methionine adenosyltransferase in vivo by S-nitrosylation. Hepatology 1998, 28, 1051-1057. [CrossRef]

170. Lu, S.C.; Huang, Z.Z.; Yang, H.; Mato, J.M.; Avila, M.A.; Tsukamoto, H. Changes in methionine adenosyltransferase and S-adenosylmethionine homeostasis in alcoholic rat liver. Am. J. Physiol. Gastrointest. Liver Physiol. 2000, 279, G178-G185. [CrossRef] [PubMed]

171. Garro, A.J.; McBeth, D.L.; Lima, V.; Lieber, C.S. Ethanol Consumption Inhibits Fetal DNA Methylation in Mice: Implications for the Fetal Alcohol Syndrome. Alcohol. Clin. Exp. Res. 1991, 15, 395-398. [CrossRef]

172. Bönsch, D.; Lenz, B.; Fiszer, R.; Frieling, H.; Kornhuber, J.; Bleich, S. Lowered DNA methyltransferase (DNMT-3b) mRNA expression is associated with genomic DNA hypermethylation in patients with chronic alcoholism. J. Neural Transm. 2006, 113, 1299-1304. [CrossRef] [PubMed]

173. Kim, Y. Nutritional epigenetics: Impact of folate deficiency on DNA methylation and colon cancer susceptibility. J. Nutr. 2005, 135, 2703-2709. [CrossRef] [PubMed]

174. Sharma, J.; Krupenko, S.A. Folate pathways mediating the effects of ethanol in tumorigenesis. Chem.-Biol. Interact. 2020, 324. [CrossRef]

175. Smith, I.M.; Mydlarz, W.K.; Mithani, S.K.; Califano, J.A. DNA global hypomethylation in squamous cell head and neck cancer associated with smoking, alcohol consumption and stage. Int. J. Cancer 2007, 121, 1724-1728. [CrossRef]

176. Chen, H.C.; Yang, C.M.; Cheng, J.T.; Tsai, K.W.; Fu, T.Y.; Liou, H.H.; Tseng, H.H.; Lee, J.H.; Li, G.C.; Wang, J.S.; et al. Global DNA hypomethylation is associated with the development and poor prognosis of tongue squamous cell carcinoma. J. Oral Pathol. Med. 2016, 45, 409-417. [CrossRef]

177. Tanaka, C.; Uzawa, K.; Shibahara, T.; Yokoe, H.; Noma, H.; Tanzawa, H. Expression of an inhibitor of apoptosis, survivin, in oral carcinogenesis. J. Dent. Res. 2003, 82, 607-611. [CrossRef]

178. Muzio, L.L.; Pannone, G.; Staibano, S.; Mignogna, M.D.; Rubini, C.; Mariggiò, M.A.; Procaccini, M.; Ferrari, F.; Rosa, G.D.; Altieri, D.C. Survivin expression in oral squamous cell carcinoma. Br. J. Cancer 2003, 89, 2244-2248. [CrossRef]

179. Gaździcka, J.; Gołąbek, K.; Strzelczyk, J.K.; Ostrowska, Z. Epigenetic Modifications in Head and Neck Cancer. Biochem. Genet. 2020, 58, 213-244. [CrossRef] [PubMed]

180. Subbalekha, K.; Pimkhaokham, A.; Pavasant, P.; Chindavijak, S.; Phokaew, C.; Shuangshoti, S.; Matangkasombut, O.; Mutirangura, A. Detection of LINE-1s hypomethylation in oral rinses of oral squamous cell carcinoma patients. Oral Oncol. 2009, 45, 184-191. [CrossRef]

181. Foy, J.P.; Pickering, C.R.; Papadimitrakopoulou, V.A.; Jelinek, J.; Lin, S.H.; William, W.N.; Frederick, M.J.; Wang, J.; Lang, W.; Feng, L.; et al. New DNA methylation markers and global DNA hypomethylation are associated with oral cancer development. Cancer Prev. Res. 2015, 8, 1027-1035. [CrossRef] [PubMed]

182. Ha, P.K.; Califano, J.A. Promoter methylation and inactivation of tumour-suppressor genes in oral squamous-cell carcinoma. Lancet Oncol. 2006, 7, 77-82. [CrossRef]

183. Zakhari, S. Alcohol metabolism and epigenetics changes. Alcohol Res. Curr. Rev. 2013, 35, 6-16.

184. Mews, P.; Egervari, G.; Nativio, R.; Sidoli, S.; Donahue, G.; Lombroso, S.I.; Alexander, D.C.; Riesche, S.L.; Heller, E.A.; Nestler, E.J.; et al. Alcohol metabolism contributes to brain histone acetylation. Nature 2019, 574, 717-721. [CrossRef] [PubMed]

185. Park, P.H.; Lim, R.W.; Shukla, S.D. Involvement of histone acetyltransferase (HAT) in ethanol-induced acetylation of histone H3 in hepatocytes: Potential mechanism for gene expression. Am. J. Physiol. Gastrointest. Liver Physiol. 2005, 289, G1124-G1136. [CrossRef] [PubMed]

186. Mancuso, M.; Matassa, D.S.; Conte, M.; Colella, G.; Rana, G.; Fucci, L.; Piscopo, M. H3K4 histone methylation in oral squamous cell carcinoma. Acta Biochim. Pol. 2009, 56, 405-410. [CrossRef]

187. Arif, M.; Vedamurthy, B.M.; Choudhari, R.; Ostwal, Y.B.; Mantelingu, K.; Kodaganur, G.S.; Kundu, T.K. Nitric oxide-mediated histone hyperacetylation in oral cancer: Target for a water-soluble HAT inhibitor, CTK7A. Chem. Biol. 2010, 17, 903-913. [CrossRef]

188. Park, P.H.; Miller, R.; Shukla, S.D. Acetylation of histone H3 at lysine 9 by ethanol in rat hepatocytes. Biochem. Biophys. Res. Commun. 2003, 306, 501-504. [CrossRef]

189. Kim, J.S.; Shukla, S.D. Acute in vivo effect of ethanol (binge drinking) on histone H3 modifications in rat tissues. Alcohol Alcohol. 2006, 41, 126-132. [CrossRef]

190. Kurdistani, S.; Tavazoie, S.; Grunstein, M. Mapping global histone acetylation patterns to gene expression. Cell 2004, 117, 721-733. [CrossRef]

191. Barski, A.; Cuddapah, S.; Cui, K.; Roh, T.; Schones, D.; Wang, Z.; Wei, G.; Chepelev, I.; Zhao, K. High-resolution profiling of histone methylations in the human genome. Cell 2007, 129, 823-837. [CrossRef] [PubMed]

192. Alexandrov, L.B.; Nik-Zainal, S.; Wedge, D.C.; Campbell, P.J.; Stratton, M.R. Deciphering signatures of mutational processes operative in human cancer. Cell Rep. 2013, 3, 246-259. [CrossRef] [PubMed] 
193. Alexandrov, L.B.; Stratton, M.R. Mutational signatures: The patterns of somatic mutations hidden in cancer genomes. Curr. Opin. Genet. Dev. 2014, 24, 52. [CrossRef] [PubMed]

194. Ma, J.; Setton, J.; Lee, N.Y.; Riaz, N.; Powell, S.N. The therapeutic significance of mutational signatures from DNA repair deficiency in cancer. Nat. Commun. 2018, 9, 1-12. [CrossRef]

195. Mutation Signatures v3. Available online: https:// cancer.sanger.ac.uk/signatures/ (accessed on 14 June 2021).

196. Alexandrov, L.B.; Nik-Zainal, S.; Wedge, D.C.; Aparicio, S.A.; Behjati, S.; Biankin, A.V.; Bignell, G.R.; Bolli, N.; Borg, A.; Børresen-Dale, A.L.; et al. Signatures of mutational processes in human cancer. Nature 2013, 500, 415-421. [CrossRef]

197. Roberts, S.A.; Lawrence, M.S.; Klimczak, L.J.; Grimm, S.A.; Fargo, D.; Stojanov, P.; Kiezun, A.; Kryukov, G.V.; Carter, S.L.; Saksena, G.; et al. An APOBEC cytidine deaminase mutagenesis pattern is widespread in human cancers. Nat. Genet. 2013, 45, 970-976. [CrossRef]

198. Alexandrov, L.B.; Kim, J.; Haradhvala, N.J.; Huang, M.N.; Tian Ng, A.W.; Wu, Y.; Boot, A.; Covington, K.R.; Gordenin, D.A.; Bergstrom, E.N.; et al. The repertoire of mutational signatures in human cancer. Nature 2020, 578, 94-101. [CrossRef] [PubMed]

199. Kucab, J.E.; Zou, X.Q.; Morganella, S.; Joel, M.; Nanda, A.S.; Nagy, E.; Gomez, C.; Degasperi, A.; Harris, R.; Jackson, S.P.; et al. A Compendium of Mutational Signatures of Environmental Agents. Cell 2019, 117, 821-836. [CrossRef]

200. Matsuda, T.; Kawanishi, M.; Yagi, T.; Matsui, S.; Takebe, H. Specific tandem GG to TT base substitutions induced by acetaldehyde are due to intra-strand crosslinks between adjacent guanine bases. PubMed-NCBI. Nucleic Acids Res. 1998, 26, 1769-1774. [CrossRef]

201. Chang, J.; Tan, W.; Ling, Z.; Xi, R.; Shao, M.; Chen, M.; Luo, Y.; Zhao, Y.; Liu, Y.; Huang, X.; et al. Genomic analysis of oesophageal squamous-cell carcinoma identifies alcohol drinking-related mutation signature and genomic alterations. Nat. Commun. 2017, 8, 15290. [CrossRef]

202. Li, X.C.; Wang, M.Y.; Yang, M.; Dai, H.J.; Zhang, B.F.; Wang, W.; Chu, X.L.; Wang, X.; Zheng, H.; Niu, R.F.; et al. A mutational signature associated with alcohol consumption and prognostically significantly mutated driver genes in esophageal squamous cell carcinoma. Ann. Oncol. 2018, 29, 938-944. [CrossRef]

203. Letouzé, E.; Shinde, J.; Renault, V.; Couchy, G.; Blanc, J.F.; Tubacher, E.; Bayard, Q.; Bacq, D.; Meyer, V.; Semhoun, J.; et al. Mutational signatures reveal the dynamic interplay of risk factors and cellular processes during liver tumorigenesis. Nat. Commun. 2017, 8, 1315. [CrossRef]

204. Supek, F.; Lehner, B. Clustered Mutation Signatures Reveal that Error-Prone DNA Repair Targets Mutations to Active Genes. Cell 2017, 170, 534-547.e23. [CrossRef] [PubMed]

205. Sonohara, Y.; Yamamoto, J.; Tohashi, K.; Takatsuka, R.; Matsuda, T.; Iwai, S.; Kuraoka, I. Acetaldehyde forms covalent GG intrastrand crosslinks in DNA. Sci. Rep. 2019, 9, 660. [CrossRef] [PubMed]

206. Chen, J.M.; Férec, C.; Cooper, D.N. Patterns and mutational signatures of tandem base substitutions causing human inherited disease. Hum. Mutat. 2013, 34, 1119-1130. [CrossRef] [PubMed]

207. Imielinski, M.; Berger, A.H.; Hammerman, P.S.; Hernandez, B.; Pugh, T.J.; Hodis, E.; Cho, J.; Suh, J.; Capelletti, M.; Sivachenko, A.; et al. Mapping the hallmarks of lung adenocarcinoma with massively parallel sequencing. Cell 2012, 150, 1107-1120. [CrossRef]

208. Stransky, N.; Egloff, A.M.; Tward, A.D.; Kostic, A.D.; Cibulskis, K.; Sivachenko, A.; Kryukov, G.V.; Lawrence, M.S.; Sougnez, C.; McKenna, A.; et al. The mutational landscape of head and neck squamous cell carcinoma. Science 2011, 333, 1157-1160. [CrossRef]

209. Plath, M.; Gass, J.; Hlevnjak, M.; Li, Q.; Feng, B.; Hostench, X.P.; Bieg, M.; Schroeder, L.; Holzinger, D.; Zapatka, M.; et al. Unraveling most abundant mutational signatures in head and neck cancer. Int. J. Cancer 2021, 148, 115-127. [CrossRef] [PubMed] 